\title{
Assessment of reservoir sedimentation effect on coastal erosion in the case of Nestos River, Greece
}

\author{
M. ANDREDAKI ${ }^{1}$, A. GEORGOULAS ${ }^{2}$, V. HRISSANTHOU ${ }^{3}$ \\ and N. KOTSOVINOS ${ }^{3}$
}

${ }^{1}$ Ph.D. candidate, Department of Civil Engineering, Democritus University of Thrace, 67100 Xanthi, Greece, E-mail: mandreda@ civil.duth.gr

${ }^{2}$ Dr., Research Associate, Department of Civil Engineering, Democritus University of Thrace, 67100 Xanthi, Greece, E-mail: ageorg@civil.duth.gr (corresponding author) ${ }^{3}$ Prof., Department of Civil Engineering, Democritus University of Thrace, 67100 Xanthi, Greece, E-mail: vhrissan@ civil.duth.gr, kotsovin@ civil.duth.gr

\begin{abstract}
Coastal erosion that is generated by the reduction of the annual sediment yield at river outlets, due to the construction of reservoirs, constitutes one of the main environmental problems in many parts of the world. Nestos is one of the most important transboundary rivers, flowing through Bulgaria and Greece, characterized by its great biodiversity. In the Greek part of the river, two reservoirs, the Thisavros Reservoir and the Platanovrysi Reservoir, have already been constructed and started operating in 1997 and 1999, respectively. The present paper constitutes the first attempt where the assessment of reservoir sedimentation effect on the coastal erosion for the case of the Nestos River delta and the adjacent shorelines is addressed in detail, through mathematical modeling, modern remote sensing techniques and field surveying. It is found that the construction and operation of the considered reservoirs have caused a dramatic decrease (about $83 \%$ ) in the sediments supplied directly to the basin outlet and indirectly to the neighbouring coast and that this fact has almost inversed the erosion/accretion balance in the deltaic as well as the adjacent shorelines. Before the construction of the reservoirs, accretion predominated erosion by $25.36 \%$, while just within five years after the construction of the reservoirs, erosion predominates accretion by $21.26 \%$.
\end{abstract}

Key words: Sediment transport, Reservoir sedimentation, Coastal erosion, Shoreline change monitoring, Nestos River. 


\section{Introduction}

Coastal erosion constitutes one of the main environmental problems in many parts of the world. Especially in the case of deltaic regions, the construction of dams in the river basin impedes sediment supply at the river mouths and therefore the rates of shoreline retreat and sea level rise may exceed the corresponding rates of vertical shoreline accretion, resulting to the increase and in many cases the predomination of deltaic and coastal erosion. Over the last decades, many investigations have been directly or indirectly focused on the assessment of dam sedimentation and its effect on sediment yield reduction and coastal erosion, in the wider coastal regions of various rivers worldwide, using varying study methodologies and techniques (e.g. Ly, 1980; Chen and Zong, 1998; El-Raey et al., 1999; Snoussi et al., 2002; Malini and Rao, 2004; Chen et al., 2008; Liu et al., 2008; Huang, 2011; Zhang et al., 2011).

Nestos is one of the most important transboundary rivers, characterized by its great biodiversity. Nestos River flows through two European countries, Bulgaria and Greece, and discharges its water into the Aegean Sea. It originates from Mount Rila (2716 m) in South Bulgaria between the mountain chains of Aimos and Rodopi, where the river is called Mesta. Its total length reaches $234 \mathrm{~km}$ and the river basin covers an area of $5749 \mathrm{~km}^{2}, 130 \mathrm{~km}\left(<56\right.$ per cent) and $2280 \mathrm{~km}^{2}(<40$ per cent) of which lie in Greek territory (Samaras and Koutitas, 2008).

In the Greek part of the river, two dams, the Thisavros Dam and the Platanovrysi Dam, have already been constructed and started operating in 1997 and 1999, respectively. The construction of the dams implies a reduction of sediment yield at the outlet of the Nestos River basin and the alteration of the sediment balance of the basin in general, which results in coastal erosion. However, the reduction of the sediment yield at the outlet of the considered river due to the construction of the two dams, as well as the increase in the coastal erosion of the deltaic and the adjacent coastal regions have never been evaluated and correlated previously.

According to the authors' best knowledge, in the present paper, it is the first time that the assessment of dam sedimentation effect on the coastal erosion for the case of the Nestos River delta and the adjacent shorelines is addressed in detail through mathematical modeling, remote sensing techniques and field surveying. The main objectives are to evaluate the overall reduction of the sediment yield at the outlet of the river due to the construction of the two dams and to examine the resulting erosion/accretion response of the deltaic as well as the adjacent shorelines. For this 
purpose, the sediment yield at the outlet of the Nestos River basin before and after the construction of the two dams is calculated, through the application of a mathematical simulation model. The model is initially tested against appropriate field measurements that are available in the literature (Section 3 of the present paper). Moreover, a shoreline change monitoring methodology for the coastal region of the Nestos River delta and the adjacent shorelines is proposed, tested and applied for the digital and detailed extraction of the shoreline position with respect to time, aiming to determine the erosion / accretion shoreline balance for two time periods that roughly correspond to the periods before and after the construction of the proposed dams. Finally, the mathematically calculated reduction of the sediment yield at the outlet of the river is correlated with the results from the application of the shoreline change monitoring methodology and some valuable conclusions and recommendations are drawn (Sections 4 and 5 of the present paper).

The mathematical simulation model that was applied to the Nestos River basin calculates the mean annual value of sediment yield, due to rainfall and runoff. The proposed model consists of three submodels: a rainfall-runoff submodel, a soil erosion submodel and a sediment transport submodel for streams, which are briefly described in Section 2 of the present paper. Additional information about the submodels is reported in Hrissanthou et al. (2010). Furthermore, a classification of soil erosion models, as well as of stream sediment transport (total load) models can be found in Hrissanthou et al. (2010).

The coastal erosion/accretion monitoring data that were used in order to determine the shoreline position with respect to time, consist of remote sensing data from high resolution satellite images and aerial photographs, as well as from high resolution DGPS (Differential Global Positioning System) field measurements. Details regarding the methodology that was followed for the shoreline extraction from the proposed images as well as from the field measurements, are described in Section 4.

\section{Description of the mathematical simulation model}

\subsection{Rainfall-runoff submodel}

By means of the rainfall-runoff submodel, the runoff depth for a certain rainfall depth is computed. It is a simplified water balance model (Giakoumakis et al., 
1991), in which the variation of soil moisture due to rainfall, evapotranspiration, deep percolation and runoff is considered. The basic balancing equation is:

$$
S_{n}^{\prime}=S_{n-1}+N_{n}-E_{p n}
$$

where $S_{n-1}$ is the available soil moisture for the time step $n-1(\mathrm{~mm}) ; N_{n}$ is the rainfall depth for the time step $n(\mathrm{~mm}) ; E_{p n}$ is the potential evapotranspiration for the time step $n(\mathrm{~mm})$ and $S_{n}^{\prime}$ is an auxiliary variable $(\mathrm{mm})$.

The direct runoff depth $h_{o n}(\mathrm{~mm})$ and the deep percolation $I N_{n}(\mathrm{~mm})$ for the time step $n$ can be evaluated by comparing $S_{n}{ }^{\prime}$ with the maximum available soil moisture $S_{\max }(\mathrm{mm})$, that is estimated by the following relationship of the US Soil Conservation Service (SCS, 1972):

$$
S_{\max }=25.4[(1000 / C N)-10]
$$

where $C N$ is the curve number depending on the soil cover, the hydrologic soil group and the antecedent soil moisture conditions $(0<C N<100)$.

In the present study, two different methods were used for the estimation of the potential evapotranspiration $E_{p}$ : the radiation method improved by Doorenbos and Pruitt (1977) was used for the Greek part of Nestos River basin, while the method of Thornthwaite (1948) was used for the Bulgarian part of Nestos River basin.

The following meteorological data are required for the application of the radiation method: mean daily temperature $\left({ }^{\circ} \mathrm{C}\right)$, sunlight hours per day (hr/day), mean daily relative humidity $(\%)$ and mean daily wind velocity $(\mathrm{m} / \mathrm{s})$. These data were available in the Greek part of Nestos River basin. For the application of the method of Thornthwaite, only mean daily temperature data $\left({ }^{\circ} \mathrm{C}\right)$ are required, which were available in the Bulgarian part of Nestos River basin.

According to the equations given above, apart from the meteorological data, the input data for the rainfall-runoff submodel are: monthly rainfall depth, altitude, latitude, soil cover - land use, and hydrologic soil group.

\subsection{Soil erosion submodel}

The soil erosion submodel is based on the assumption that the impact of droplets on the soil surface and the surface runoff are proportional to the momentum flux contained in the droplets and the runoff, respectively (Schmidt, 1992). 
The momentum flux exerted by the falling droplets, $\varphi_{r}\left(\mathrm{~kg} \mathrm{~m} / \mathrm{s}^{2}\right)$, is given by:

$$
\varphi_{r}=\operatorname{Cr} \rho A u_{r} \sin a
$$

where $C$ is the soil cover factor; $r$ is the rainfall intensity $(\mathrm{m} / \mathrm{s}) ; \rho$ is the water density $\left(\mathrm{kg} / \mathrm{m}^{3}\right) ; A$ is the sub-basin area $\left(\mathrm{m}^{2}\right) ; u_{r}$ is the mean fall velocity of the droplets $(\mathrm{m} / \mathrm{s})$ and $\alpha$ is the mean slope angle of the soil surface $\left(^{\circ}\right)$.

The original relationship of Schmidt for the momentum flux exerted by the droplets is valid for bare soils. Therefore, an additional factor is necessary to express the decrease of the momentum flux because of the vegetation. It is believed that the dimensionless crop and mamagement factor $C$ of the USLE (Universal Soil Loss Equation; Wischmeier and Smith, 1978) is appropriate to express the vegetation influence.

The momentum flux exerted by the runoff, $\varphi_{f}\left(\mathrm{~kg} \mathrm{~m} / \mathrm{s}^{2}\right)$, is given by:

$$
\varphi_{f}=q \rho b u
$$

where $q$ is the direct runoff rate per unit width $\left[\mathrm{m}^{3} /(\mathrm{s} \mathrm{m})\right] ; b$ is the width of the subbasin area $(\mathrm{m}) ; u$ is the mean flow velocity $(\mathrm{m} / \mathrm{s})$.

The available sediment discharge per unit width, $q_{r f}[(\mathrm{~kg} /(\mathrm{m} \mathrm{s})]$, due to rainfall and runoff, in the sub-basin considered is given by (Schmidt, 1992):

$$
q_{r f}=(1.7 E-1.7) 10^{-4}
$$

where

$$
E=\left(\varphi_{r}+\varphi_{f}\right) / \varphi_{c r} \quad(E>1)
$$

and $\varphi_{c r}$ is the critical momentum flux $\left(\mathrm{kg} \mathrm{m} / \mathrm{s}^{2}\right)$.

The critical momentum flux $\varphi_{c r}$, which designates the soil erodibility, can be calculated from:

$$
\varphi_{c r}=q_{c r} \rho b u
$$

where $q_{c r}\left[\mathrm{~m}^{3} /(\mathrm{s} \mathrm{m})\right]$ is the direct runoff rate per unit width at initial erosion.

The critical runoff rate $q_{c r}$ is determined from the critical erosion velocity depending on soil roughness.

Equation (6) suggests the concept of critical situation characterizing the initiation of sediment motion on the soil surface. 
The sediment supply $E S[(\mathrm{~kg} /(\mathrm{s} \mathrm{m})]$ to the main stream of the sub-basin

considered is estimated by means of a comparison between the available sediment discharge $q_{r f}$ in the sub-basin and the sediment transport capacity by overland flow per unit width, $q_{t}[\mathrm{~kg} /(\mathrm{s} \mathrm{m})]$, which is computed as follows (Schmidt, 1992):

$$
q_{t}=c_{\max } \rho_{s} q
$$

where $c_{\max }$ is the concentration of suspended particles at transport capacity $\left(\mathrm{m}^{3} / \mathrm{m}^{3}\right)$; $\rho_{s}$ is the sediment density $\left(\mathrm{kg} / \mathrm{m}^{3}\right)$.

The additional input data for the soil erosion submodel, with reference to the rainfall-runoff submodel, are: mean slope angle of soil surface, sub-basin area, soil cover factor, length of the main stream of the sub-basins, roughness coefficient of soil surface, critical erosion velocity, water and sediment density.

\subsection{Stream sediment transport submodel}

The sediment yield at the outlet of the main stream of the sub-basin considered can be computed by the concept of sediment transport capacity by the stream flow. The following relationships are used to compute sediment transport capacity by the stream flow (Yang, 1973):

$$
\begin{gathered}
\log c_{t}=5.435-0.286 \log \frac{w D_{50}}{v}-0.457 \log \frac{u_{*}}{w}+ \\
+\left(1.799-0.409 \log \frac{w D_{50}}{v}-0.314 \log \frac{u_{*}}{w}\right) \log \left(\frac{u s}{w}-\frac{u_{c r} s}{w}\right) \\
\frac{u_{c r}}{w}=\frac{2.5}{\log \left(u_{*} D_{50} / v\right)-0.66}, \text { if } 1.2<u_{*} D_{50} / v<70 \\
\frac{u_{c r}}{w}=2.05, \text { if } \frac{u_{*} D_{50}}{v} \geq 70
\end{gathered}
$$

where $c_{t}$ is the total sediment concentration by weight (ppm); $w$ is the terminal fall velocity of suspended particles $(\mathrm{m} / \mathrm{s}) ; D_{50}$ is the median grain diameter of the bed material $(\mathrm{m}) ; v$ is the kinematic viscosity of the water $\left(\mathrm{m}^{2} / \mathrm{s}\right) ; u_{*}$ is the shear velocity $(\mathrm{m} / \mathrm{s}) ; u$ is the mean flow velocity $(\mathrm{m} / \mathrm{s}) ; u_{c r}$ is the critical mean flow velocity $(\mathrm{m} / \mathrm{s})$ and $s$ is the energy slope.

Equation (9) was determined from the concept of unit stream power (rate of potential energy expenditure per unit weight of water, $u s$ ) and dimensional analysis. 
The variable $u_{c r}$ in Eq. (9) suggests that a critical situation is considered at the beginning of sediment particle motion, as in most sediment transport equations.

The sediment yield $F L O[\mathrm{~kg} /(\mathrm{s} \mathrm{m})]$ at the outlet of the main stream of the sub-basin considered can be estimated by comparing the available sediment in the stream, ESI $[\mathrm{kg} /(\mathrm{s} \mathrm{m})]$, with the transport capacity by the stream flow, $q_{t s}[\mathrm{~kg} /(\mathrm{s}$ m)], resulting from the total sediment concentration $c_{t}$.

It is implied from the above relationships that only the main stream of each sub-basin is considered, because numerous unavailable data for the geometry and hydraulics of the entire stream system would otherwise be required. Therefore, the additional input data for the stream sediment transport submodel, with reference to the foregoing submodels, concern the main stream of the sub-basins: base flow, bottom slope, bottom width, bed roughness, diameter of suspended particles, grain diameter of bed material, and kinematic viscosity of water.

Finally, a sediment routing plan is necessary in order to specify the sediment motion from sub-basin to sub-basin.

\section{Application of the simulation model}

\subsection{Available data and maps for Nestos River basin}

For more precise calculations, the Nestos River basin was divided into 60 subbasins. Specifically, the basin of the Thisavros Dam (Bulgarian and Greek parts) was divided into 31 sub-basins, the basin of the Platanovrysi Dam (Greece) into nine subbasins and the basin downstream of the Platanovrysi Dam into 20 sub-basins. The outlet of the last basin is named Toxotes.

Meteorological data (mainly monthly rainfall data and mean monthly temperature data) from 22 meteorological stations in Greece and Bulgaria were used as input data for the simulation model. Various digital thematic maps were constructed from georeferenced background maps, for the accurate computation of the sub-basins parameters. Indicatively, the sub-basins and main streams map as well as the soil cover map are illustrated in Figure 1 and the Thiessen polygons map and the geological map in Figure 2. The values of the sub-basin parameters (e.g. sub-basin area, mean slope gradient of soil surface, mean slope gradient of the main stream of a sub-basin, percentage of Thiessen polygons, percentage of soil cover etc.) were also used as input data for the model as mentioned in the preceding sections. 
The calculations were performed for each sub-basin on a monthly time basis.

This means that cumulative monthly values for runoff, soil erosion and sediment transport were calculated for each sub-basin; thus, the impact of extreme rainfall events can be recognised indirectly by the relatively high arithmetic values of the corresponding monthly runoff and soil erosion.

\subsection{Model testing}

Sediment measurements (suspended load) for 53 years (1937-1989) were available for the location "Momina Koula" (Gergov, 1996) in the Bulgarian part of Nestos River (Figure 1). According to the measurements, the mean annual suspended sediment yield for the time period given above is $202 \mathrm{t} / \mathrm{km}^{2}$ (Gergov, 1996).

Bed load measurements were not available; therefore, the following assumption (Andredaki et al., 2011) was made: the ratio of bed load to suspended load at the outlet of a basin on an annual basis amounts approximately to 0.25 . According to this assumption, the measured mean annual sediment yield at "Momina Koula" is $252.5 \mathrm{t} / \mathrm{km}^{2}$.

The simulation model described above was applied to the basin corresponding to this location for the same time period (Andredaki et al., 2011). The basin area is $1511 \mathrm{~km}^{2}$, which is about $30 \%$ of the entire basin area of the Nestos River. The arithmetic results of the model for the different years are given in Table 1. The mean annual value of sediment yield at the basin outlet, according to Table 1, is $315000 \mathrm{t}$ or $207.9 \mathrm{t} / \mathrm{km}^{2}$. This means that the mathematical model used underestimates the measured mean annual sediment yield by about $18 \%$. However, taking into account the overall assumptions of the mathematical model as well as the complexity of the simulated process, the atithmetic predictions can be considered to be acceptable.

\subsection{Main computations of sediment yield}

The relatively low deviation between computation and measurement results for the mean annual sediment yield at the location "Momina Koula" was an encouraging indication for the further application of the simulation model to other parts of the Nestos River basin. The following calculations were therefore performed for a time period of eleven years (1980-1990) that corresponds to the period before the construction and operation of the Thisavros and Platanovrysi Dams: 

Reservoir from the Bulgarian part $\left(3052 \mathrm{~km}^{2}\right)$ and from the Greek part (804 $\mathrm{km}^{2}$ ) of the Nestos River basin (Andredaki et al., 2011; Kapona and Tona, 2003).

b. Calculation of mean annual sediment amount inflowing into the Platanovrysi Reservoir from the corresponding basin (405 km², Greece) (Klisiari, 2002).

c. In a previous study (Hrissanthou, 2002), the mean annual value of sediment yield at the outlet of the Nestos River basin (Toxotes) was calculated. The sediment yield originates mainly from the part of the Nestos River basin which lies downstream of the Platanovrysi Dam $\left(840 \mathrm{~km}^{2}\right.$, Greece).

The calculated values of the annual sediment yield for different years at certain locations of the Nestos River basin (Thisavros Reservoir, Platanovrysi Reservoir and Toxotes) are summarized in Table 2.

For the above calculations, the following assumption was made: All sediments inflowing into the reservoirs are deposited in the reservoirs. This assumption may be the most unfavourable case regarding coastal erosion.

If systematic measurements of sediment yield at the outlet of Nestos River basin, before and after the dam construction, were available, then the application of the mathematical simulation model described above would not have been necessary.

According to Table 2, the mean annual value of sediment yield at the outlet of the Nestos River basin before the construction of the dams (mean annual value of sediment yield at the outlet of the entire Nestos River basin) is about $1.9 \times 10^{6} \mathrm{t}$, while after the construction of the dams (mean annual value of sediment yield at the outlet of basin downstream of the Platanovrysi Dam) this amounts to $0.33 \times 10^{6}$ t. Therefore, it can be concluded that the construction of the considered dams has caused a dramatic decrease (about 83\%) in the sediments supplied directly to the basin outlet and indirectly to the neighbouring coast. The Nestos River constitutes one of the main sediment supply sources for the west and east parts of the coastal region in the vicinity of its delta. Therefore, the calculated reduction in the sediment yield that reaches the Nestos River mouth, influences the seashore sediment balance and as it will be shown in the next sections of the present paper, it results in a considerable increase in the erosion rates of the Nestos River mouth and the adjacent shorelines. 


\section{Description and testing of adopted methodology, for shoreline change monitoring}

4.1 Overview

The adopted shoreline change monitoring methodology for the Nestos River delta and the adjacent shorelines was the use of available high resolution satellite images from the QuickBird (QB) satellite archive and aerial photographs from the Hellenic Military Geographical Service (HMGS), in conjunction with high resolution GPS field measurements of the region. In more detail:

- Use of ortho-rectified/geo-referenced, satellite images that were available in the QB archive for the extraction of the shoreline in the year 2002. The spatial resolution of these satellite images is $0.6 \mathrm{~m}$ per pixel. The proposed year was selected as it was more close to the years 1997 and 1999 during which the Thisavros Dam and the Platanovrysi Dam operation, respectively, had started.

- Use of high resolution DGPS field measurements for the extraction of the shoreline in the year 2007, in order to obtain the shoreline state approximately a decade after the operation of the considered dams. The accuracy of these field measurements can reach the order of few centimeters.

- Comparison of the extracted shorelines between the above two time periods in order to access a short term shoreline evolution of the region that roughly corresponds to the period after the construction of the dams.

- Ortho-rectification/geo-referencing of available, old aerial photographs of the region from the year 1945 from the HMGS and extraction of an old shoreline, approximately 50 years before the construction and operation of the dams.

- Comparison of the extracted shorelines between the years 1945 and 2002 in order to access a long term shoreline evolution of the region that roughly corresponds to the period before the construction of the dams. 
In order to test the accuracy of the adopted shoreline change monitoring methodology, this was first applied to a small part of the total pilot study region (Figure 3). The proposed test part is composed by the mainland shoreline at the west of Nestos River delta extending from the Akroneri Cape until the Keramoti Bay.

\subsection{Step 1 - Creation of common working background}

In order to use a common, user-friendly working sub-base, an ortho-rectified background of the wider geographical region was created using various available topographic maps from the HMGS. The merging and ortho-rectification of the proposed maps was conducted in ArcMap software from the ArcGIS 9 package, using as Ground Control Points (GCP's) a wide scatter of known, benchmark, trigonometric points of the region that were provided by the HMGS. The "Greek Grid" coordinate system was used.

\subsection{Step 2 - Ortho-rectification of aerial photographs and extraction of digital shoreline}

The ortho-rectification of the available old aerial photographs of the region and the digital extraction of the corresponding shoreline was conducted with the ArcMap software of the ArcGIS 9 package. The basic stages of the proposed procedure are summarised below:

- The aerial photographs were scanned and digitally imported into the ArcMap database in order to be ortho-rectified in the EGSA 87 coordinate system, using as GCP's, points that were both visible in the aerial photographs as well as in the ortho-rectified map background (Section 4.1). These GCP's were mainly cross-roads, bridge supports, harbour piers, building edges etc. A total number of 6-8 GCP's were used for each aerial photograph.

- A surface analysis was then performed in the ortho-rectified aerial photographs and automatic contours were generated.

- Finally, the contour that corresponded to the dividing line between land and sea pixels, was manually selected by visual inspection and digitally extracted as the shoreline position in the year 1945. The accuracy and validity of the proposed automatically extracted shoreline was then checked by careful visual 
inspection zooming in various parts of the digital shoreline which was superimposed on the aerial photographs.

Figure 4 illustrates the digitally extracted shoreline for the testing region (year 1945) superimposed on the corresponding aerial photograph, together with two indicative zoomed parts where the adequate accuracy and the validity of the extraction method described above can be clearly seen.

\subsection{Step 3 - Ortho-rectification of high resolution satellite images and extraction of digital shoreline}

The digital shoreline extraction from the ortho-rectified, high resolution, satellite images of the region was also conducted using the ArcMap software of the ArcGIS 9 package. The basic stages of the proposed procedure are summarised below:

- Ortho-rectified, QB satellite images of the pilot study region were selected and ordered from the archive database of GEOMED LTD which is one of the authorised resellers of these images for the region of East Macedonia and Thrace, in Greece.

- The proposed 4-band satellite images were then imported into the ArcMap database in the EGSA 87 coordinate system and adjusted to the infrared channel, where the colour differentiation of sea and land pixels is more visible.

- The well-known "Natural Breaks (Jenks)" pixel classification method was then applied on the infrared channel of the images, from the "spatial analyst" tool of the ArcMap software, in order to separate sea and land pixels.

- Then a contour line was automatically inserted at the interface of the classified sea and land pixels and digitally extracted as the shoreline.

- In order to check the accuracy and validity of the extracted shoreline, the classified images were then readjusted to the RGB panchromatic channel (initial state) and were visually inspected by zooming in, at various parts of the shoreline.

Figure 5 illustrates the digitally extracted shoreline for the testing region (year 2002) superimposed on the corresponding satellite images, together with two indicative zoomed parts where the adequate accuracy and the validity of the extraction method described above can be clearly seen. 
4.5 Step 4 - DGPS field measurements and extraction of digital shoreline

The DGPS field measurements were conducted using a high resolution DGPS system that consists of two GPS receivers. A static receiver that was installed at various, known, benchmark, trigonometric points of the region that were pre-installed by the HMGS and a rover (mobile) receiver which was used for the surveying of the shoreline in the field. The recorded data points from the rover receiver along the shoreline were then post-processed and extracted in AutoCAD files in the EGSA 87 coordinate system and finally imported superimposed at the ArcMap database. The accuracy of the used DGPS system was estimated to be of the order of few centimetres. Figure 6 illustrates the resulted digital shoreline for the test region (year 2007), superimposed on the QB satellite images into the ArcMap database. The accuracy of the DGPS measurements according to the specifications of the proposed equipment was of the order of few centimetres. However, this was double-checked and verified using GCP's with known coordinates.

\section{Quantitative and qualitative results from the application of the selected shoreline change monitoring methodology at the entire pilot study area} 5.1 General

The various stages for the application of the adopted shoreline change monitoring methodology were described in detail in the previous section of the paper. In the present section, the overall quantitative and qualitative results from the application of the proposed methodology in the entire pilot study region are presented and discussed in detail. Figures 7, 8 and 9 illustrate indicatively some stages of the application for the entire pilot study area. In more detail, the digitally extracted shoreline (green line) from the aerial photographs (year 1945) for the entire pilot study region, superimposed on the ortho-rectified aerial photographs is illustrated in Figure 7. The ortho-rectified mosaic of the HMGS maps for the wider geographical region, that was used in order to ortho-rectify the aerial photographs can be seen at the background, behind the aerial photographs. The corresponding digitally extracted shoreline from the high resolution satellite images (year 2002) as well as from the DGPS field measurements (year 2007), are depicted in Figures 8 (red line) and 9 (blue line), respectively. 
5.2 Shoreline evolution maps for the region of the Nestos River delta and the adjacent shorelines

In the present sub-section of the paper, shoreline evolution maps are presented for hot spots of erosion/accretion areas that were selected from the entire pilot study region (Figures 10-12), in order to investigate the dynamic response of the shoreline with respect to time, before and after the construction of the dams, for regions that are subjected to severe shoreline erosion/accretion.

In more detail, Figure 10 depicts the resulting shoreline change map for the Akroneri cape region. As it can be seen, before the construction of the dams (time period 1945-2002), the considered region has been mainly subjected to severe erosion, while after the construction of the dams (time period 2002-2007) it is still subjected to erosion but at a much smaller magnitude.

Figure 11 depicts the corresponding shoreline change map for the Keramoti bay region. As it can be seen, before the construction of the dams (time period 19452002), the considered region has been mainly subjected to severe accretion, while after the construction of the dams (time period 2002-2007) it is still mainly subjected to accretion but at a much smaller magnitude.

The corresponding shoreline change map for the Nestos River delta region is illustrated in Figure 12. As it can be seen, before the construction of the dams (time period 1945-2002), the considered region has been mainly subjected to severe accretion, while after the construction of the dams (time period 2002-2007) it is subjected to both erosion as well as accretion at a quite considerable magnitude.

From the overall examination of the considered maps, it can be concluded that shoreline erosion and/or accretion is quite intense in these hot spots of the entire pilot study area, both from a short-term point of view (time period 2002-2007) as well as from a long-term point of view (time period 1945-2002), with shoreline evolution rates reaching almost $30 \mathrm{~m}$ per year, at the Nestos River delta. The calculated maximum erosion/accretion rates for the wider regions of Akroneri Cape, Keramoti Bay and Nestor River delta are summarized in Table 3. From this table, it is evident again that the Akroneri Cape region is subjected to quite intense erosion rates both before and after the construction of the dams. On the contrary, the Keramoti Bay region suffers from quite intense accretion rates, again both before and after the construction of the dams. Finally, in the Nestos River delta region, before the 
construction of the dams, accretion was the dominant mechanism, with maximum rates reaching $17.7 \mathrm{~m} /$ year. However, after the construction of the dams, both erosion and accretion mechanisms are present with quite intense rates, reaching $26.7 \mathrm{~m} /$ year and $30 \mathrm{~m} /$ year, respectively. This different shoreline response between these three hot spot regions of the considered shoreline can probably be attributed to the fact that the main alongshore current in the overall region is directed from the east to the west. Hence, the coastal sediment that are lost from the river delta due to erosion are transported to the west and deposited in the Keramoti Bay region that acts as a physical barrier between the Nestos River delta region and the Acroneri Cape region (Figure 3). However, the quite intense erosion rates at the Nestos River delta after the construction of the dams (time period 2002-2007), which were almost absent at the time period before the construction of the dams (time period 1945-2002), indicate that the construction of the considered dams and the consequent reduction of the sediment yield at the outlet of the Nestos River, has dramatically changed the dynamic response of the shoreline.

\subsection{Calculation of erosion/accretion balance for the region of the Nestos River delta} and the adjacent shorelines, before and after the construction of the dams

In order to investigate the erosion/accretion balance between the years 1945 and 2002 (time period before the construction of the dams) and the years 2002 to 2007 (time period after the construction of the dams), polygons that represent eroded and accreted areas were extracted from the ArcMap database. These are illustrated in Figure 14 for the two different time periods, respectively. The boundaries of these polygons are defined by the non-intersecting parts of the digitally extracted shorelines in each of the examined time periods. The area of the considered polygons and the calculation of the resulting erosion/accretion balance expressed in $\mathrm{m}^{2}$ are summarized in Tables 4 and 5 for the two time periods, respectively.

As it can be observed (Table 4), from the year 1945 up to the year 2002 and for the considered shoreline (total length of $25 \mathrm{~km}$ ), the erosion was about 1335028 $\mathrm{m}^{2}\left(23421 \mathrm{~m}^{2}\right.$ per year) and the accretion $2242208 \mathrm{~m}^{2}\left(39337 \mathrm{~m}^{2}\right.$ per year), i.e. the overall balance of the eroded/accreted areas from 1945 to 2002, for a total shoreline length of approximately $25 \mathrm{~km}$ in the vicinity of the Nestos River delta, indicates that accretion is the dominant mechanism covering a total area almost 1.7 times bigger than the corresponding area of the eroded parts. In other words, accretion dominates 
erosion by $25.36 \%$. On the other hand, examining the same shoreline region from accretion $243453 \mathrm{~m}^{2}\left(48691 \mathrm{~m}^{2}\right.$ per year), i.e. the erosion mechanism dominates accretion by approximately $21.26 \%$. Therefore, it can be concluded that the dramatic decrease in the sediments supplied directly to the Nestos River basin outlet and indirectly to the neighbouring coast, due to the construction and operation of the dams, that was calculated in Section 3 of the present paper, has almost inversed the previous situation regarding the erosion-accretion balance in the considered region, just within five years after the construction of the dams. This finding evaluates the direct effect of the construction of the Thisavros and Platanovrysi Dams, to the erosion increase in the coastal region of the Nestos River delta and the adjacent shorelines.

At this point, it should be mentioned that the noticeable difference in the number of polygons between Tables 4 and 5 is due to the corresponding difference of the two time period lengths (58 years versus 6 years). In the long time period (years 1945-2002), the shoreline change is greater and therefore the coastal area that has been lost or gained, is represented by bigger and hence fewer polygons. On the other hand, in the case of the short time period (years 2002-2007), the shoreline change is smaller and more localized and therefore the coastal area that has been lost or gained, is represented by smaller and hence more polygons.

\section{Conclusions}

Coastal erosion that is generated by the reduction of the annual sediment yield at river outlets, due to the construction of dams, constitutes one of the main environmental problems in many parts of the world. Nestos is one of the most important transboundary rivers, characterized by its great biodiversity. Nestos River flows through two European countries, Bulgaria and Greece, and discharges its water into the Aegean Sea. In the Greek part of the river, two dams, the Thisavros Dam and the Platanovrysi Dam, have already been constructed and started operating in 1997 and 1999, respectively. The construction of the dams implies a reduction of sediment yield at the outlet of the Nestos River basin and the alteration of the sediment balance of the basin in general, which results to coastal erosion. The present paper deals with the assessment of reservoir sedimentation effect on the coastal erosion for the case of the Nestos River delta and the adjacent shorelines, through mathematical modeling, 
remote sensing techniques and field surveying. The mathematical model is applied for the estimation of the sediment yield reduction at the outlet of the river due to the subsequent sediment accumulation within the reservoirs, while a shoreline change monitoring methodology is applied for the estimation of the alteration of the erosion/accretion balance in the wider coastal region of Nestos River delta, examining the proposed balance in two different time periods, before and after the construction of the dams.

The mathematical model results indicate that the construction of the considered dams has caused a dramatic decrease (about 83\%) in the sediments supplied directly to the basin outlet (delta) and indirectly to the neighbouring coast. From the shoreline change monitoring results, it is evident that there are various hot spots in the entire pilot study area, with maximum shoreline evolution rates varying from 4 to $30 \mathrm{~m}$ per year both before and after the construction of the dams. However, comparing the overall balance of the eroded and accreted areas in the region, before and after the construction and operation of the dams, it can be concluded that the decrease in the sediments supplied directly to the Nestos River basin outlet and indirectly to the neighbouring coast, has almost inversed the previous situation (where accretion predominated erosion by $25.36 \%$ ), just within five years after the construction of the dams, with erosion now predominating accretion by $21.26 \%$.

Based on the above, it emerges that the construction and operation of the Thisavros and Platanovrysi Dams have significantly increased coastal erosion in the Nestos River delta and the adjacent shorelines. This fact, together with the anticipated rise of sea level, may pose a great problem to the coastal area resources, threatening the local communities and ecosystems of the considered region. Therefore, it is necessary to further investigate the sediment budget within the estuarine and the adjacent coastal systems and to further monitor erosion/accretion trends of the region for the coming decades.

Summarizing, the present work constitutes the first quantitative attempt to address the dam sedimentation effect on coastal erosion in the case of Nestos River, combining mathematical modeling with modern remote sensing techniques and field surveying. 


\section{Acknowledgements}

The authors would like to acknowledge the financial support from the Research Project, INTEREG IIIC BEACHMED-e, "Strategic management of beach protection for sustainable development of Mediterranean coastal zones". The authors would also like to thank Professor G.S. Xeidakis at the Democritus University of Thrace, for his continuous help, support and guidelines, sharing his long and valuable experience on erosion/accretion processes in the pilot study area.

\section{References}

Andredaki M., Hrissanthou V. and Kotsovinos N. 2011, Calculation of sediment reduction at the outlet of the Mesta/Nestos River basin caused by the dams, Chapter 5, Section 5.9, in: Transboundary water resources management - A multidisciplinary approach, ed. by J. Ganoulis, A. Aureli and J. Fried, Wiley-VCH, Weinheim, Germany, pp. 205-214.

Chen X. and Zong Y. 1998, Coastal erosion along the Changjiang deltaic shoreline, China: history and prospective, Estuarine, Coastal and Self Science, Vol. 46, pp. 733-742.

Chen X., Yan Y., Fu R., Dou X. and Zhang E. 2008, Sediment transport from the Yangtze River, China, into the sea over the Post-Three Gorge Dam Period: A discussion, Quaternary International, Vol. 186, pp. 55-64.

Doorenbos J. and Pruitt W. O. 1977, Crop water requirements. FAO, Irrigation and Drainage Paper 24 (revised). FAO, Rome, Italy.

El-Raey M., Sharaf El-Din S.H, Khafagy A.A. and Abo Zed A.I. 1999, Remote sensing of beach erosion/accretion patterns along Damietta-Port Said shoreline, Egypt, International Journal of Remote Sensing, Vol. 20, No. 6, pp. 1087-1106.

Gergov G. 1996, Suspended sediment load of Bulgarian rivers. GeoJournal, Vol. 40, No. 4, pp. 387-396.

Giakoumakis S., Tsakiris G. and Efremides D. 1991, On the rainfall-runoff modeling in a Mediterranean island environment. In: Advances in Water Resources Technology, ed. by G. Tsakiris, Balkema, Rotterdam, pp. 137-148.

Hrissanthou V. 2002, Comparative application of two erosion models to a basin. Hydrological Sciences Journal, Vol. 47, No. 2, pp. 279-292. 
Hrissanthou V., Delimani P. and Xeidakis G. 2010, Estimate of sediment inflow into Vistonis Lake, Greece. International Journal of Sediment Research, Vol. 25, pp. 161-174.

Huang G. 2011, Time lag between reduction of sediment supply and coastal erosion, International Journal of Sediment Research, Vol. 26, pp. 27-35.

Kapona E. and Tona E. 2003, Computation of the inflowing sediments into Thisavros Reservoir of Nestos River. Diploma Thesis, Department of Civil Engineering, Democritus University of Thrace, Xanthi, Greece (in Greek).

Klisiari A. 2002, Computation of the inflowing sediments into Platanovrysi Reservoir of Nestos River. Diploma Thesis, Department of Civil Engineering, Democritus University of Thrace, Xanthi, Greece (in Greek).

Liu C., Sui J. and Wang Z. 2008, Sediment load reduction in Chinese rivers, International Journal of Sediment Research, Vol. 23, pp. 44-55.

Ly C.K. 1980, The role of the Akosombo Dam on the Volta river in causing coastal erosion in central and eastern Ghana (West Africa), Marine Geology, Vol. 37, pp. 323-332.

Malini B.M. and Rao K.N. 2004, Coastal erosion and habitat loss along the Godavari delta front - a fallout of dam construction (?), Current Science, Vol. 87, No. 9, pp. $1232-1236$.

Samaras A.G. and Koutitas C.G. 2008, Modelling the impact on coastal morphology of the water management in transboundary river basins: The case of River Nestos, Management of Environmental Quality: An International Journal, Vol. 10, No. 4, pp. 455-466.

Schmidt J. 1992, Predicting the sediment yield from agricultural land using a new soil erosion model. Proceedings $5^{\text {th }}$ International Symposium on River Sedimentation, ed. by P. Larsen and N. Eisenhauer, Karlsruhe, Germany, pp. 1045-1051.

SCS (Soil Conservation Service) 1972, National Engineering Handbook. Section of Hydrology, SCS, Washington DC, USA.

Snoussi M., Haida S. and Imassi S. 2002, Effects of the construction of dams on the water and sediment fluxes of the Moulouya and the Sebou Rivers, Morocco, Regional Environmental Change, Vol. 3, pp. 5-12.

Thornthwaite C. W. 1948, An approach towards a rational classification of climate. Geographic Review, Vol. 38, pp. 55-94. 
Wischmeier W.H. and Smith D.D. 1973, Predicting rainfall erosion losses Aguide to conservation planning. US Department of Agriculture, Agriculture Handbook No.537, Washington DC, USA.

Yang C. T. 1973, Incipient motion and sediment transport. Journal of the Hydraulics Division, ASCE, Vol. 99, No. 10, pp. 1679-1704.

Zhang W., Mu S., Zhang Y. and Chen K. 2011, Temporal variation of suspended sediment load in the Pearl River due to human activities, International Journal of Sediment Research, Vol. 26, pp. 487-497.

\section{Figure Captions}

Figure 1: Sub-basins/main streams map and soil cover map of the Nestos River basin Figure 2: Thiessen polygons map and geological map of the Nestos River basin

Figure 3: Pilot study region for shoreline change monitoring and selected region for testing the accuracy and effectiveness of the adopted shoreline change monitoring methodology

Figure 4: Digitally extracted shoreline from the aerial photograph that corresponds to the test region (year 1945), superimposed on the aerial photograph

Figure 5: Digitally extracted shoreline from the high resolution satellite images that correspond to the test region (year 2002), superimposed on the satellite images

Figure 6: Digitally extracted shoreline from DGPS field measurements for the test region (year 2007), superimposed on the satellite images (year 2002)

Figure 7: Digitally extracted shoreline from aerial photographs (year 1945) for the entire pilot study region, superimposed on the aerial photographs

Figure 8: Digitally extracted shoreline from satellite images (year 2002) for the entire pilot study region, superimposed on the satellite images

Figure 9: Digitally extracted shoreline from DGPS measurements (year 2007) for the entire pilot study region, superimposed on the common working background

Figure 10: Shoreline change map for the Akroneri Cape region (coordinate system: "Greek Grid")

Figure 11: Shoreline change map for the Keramoti Bay region (coordinate system: "Greek Grid")

Figure 12: Shoreline change map for the Nestos River delta region (coordinate system: "Greek Grid") 
Figure 13: Shoreline change map east of the Nestos River delta region (coordinate system: “Greek Grid")

Figure 14: Eroded/accreted areas for the time periods 1945-2002 and 2002-2007

\section{Table Captions}

Table 1: Computational results of sediment yield for the location "Momina Koula" Table 2: Computational results of sediment yield at various locations of the Nestos River basin

Table 3: Estimated maximum erosion/accretion rates from the shoreline evolution maps of the pilot study region in Figures 13-18, for the time periods 1945-2002 and 2002-2007

Table 4: Areas of erosion and accretion in the pilot study region, for the time period 1945-2002

Table 5: Areas of erosion and accretion in the pilot study region, for the time period 2002-2007 
Table 1.

\begin{tabular}{|c|c|c|c|c|c|c|c||}
\hline Year & $\begin{array}{l}\text { Annual } \\
\text { sediment } \\
\text { yield (t) }\end{array}$ & Year & $\begin{array}{l}\text { Annual } \\
\text { sediment } \\
\text { yield (t) }\end{array}$ & Year & $\begin{array}{l}\text { Annual } \\
\text { sediment } \\
\text { yield (t) }\end{array}$ & Year & $\begin{array}{l}\text { Annual } \\
\text { sediment } \\
\text { yield (t) }\end{array}$ \\
\hline 1937 & 366000 & 1950 & 278500 & 1964 & 91000 & 1977 & 85500 \\
\hline 1938 & 300500 & 1951 & 428500 & 1965 & 276500 & 1978 & 280500 \\
\hline 1939 & 271500 & 1952 & 374000 & 1966 & 475500 & 1979 & 315000 \\
\hline 1940 & 447500 & 1953 & 359000 & 1967 & 107500 & 1980 & 314000 \\
\hline 1941 & 144500 & 1954 & 786000 & 1968 & 252500 & 1981 & 200500 \\
\hline 1942 & 313500 & 1955 & 381000 & 1969 & 634500 & 1982 & 209500 \\
\hline 1943 & 36000 & 1956 & 458000 & 1970 & 152500 & 1983 & 68500 \\
\hline 1944 & 327000 & 1958 & 413000 & 1971 & 511500 & 1984 & 185000 \\
\hline 1945 & 485000 & 1959 & 274000 & 1972 & 179000 & 1985 & 239000 \\
\hline 1946 & 338000 & 1960 & 555500 & 1973 & 318000 & 1986 & 511000 \\
\hline 1947 & 517500 & 1961 & 160500 & 1974 & 225000 & 1987 & 288500 \\
\hline 1948 & 72000 & 1962 & 798500 & 1975 & 55500 & 1988 & 253000 \\
\hline 1949 & 230500 & 1963 & 705500 & 1976 & 319500 & 1989 & 7500 \\
\hline \hline
\end{tabular}


Table 2.

\begin{tabular}{|c|c|l|l|l|l|l||}
\hline Year & $\begin{array}{l}\text { Basin of } \\
\text { Thisavros } \\
\text { Dam } \\
\text { (Bulgarian } \\
\text { part) (t) }\end{array}$ & $\begin{array}{l}\text { Basin of } \\
\text { Thisavros } \\
\text { Dam } \\
\text { (Greek } \\
\text { part) (t) }\end{array}$ & $\begin{array}{l}\text { Basin } \\
\text { downstream } \\
\text { of Dospat } \\
\text { Dam (t) }\end{array}$ & $\begin{array}{l}\text { Basin of } \\
\text { Platanovrysi } \\
\text { Dam (t) }\end{array}$ & $\begin{array}{l}\text { Basin } \\
\text { downstream } \\
\text { of Platano- } \\
\text { vrysi Dam } \\
(\mathrm{t})\end{array}$ & $\begin{array}{l}\text { Entire } \\
\text { basin of } \\
\text { Nestos } \\
\text { River (t) }\end{array}$ \\
\hline \hline 1980 & $\begin{array}{c}1084000 \\
184000\end{array}$ & 154500 & 366000 & 278000 & 2066500 \\
\hline 1981 & 968000 & 128000 & 128500 & 344000 & 588000 & 2156500 \\
\hline 1982 & 850000 & 312500 & 112500 & 409000 & 426000 & 2110000 \\
\hline 1983 & 309500 & 114000 & 32500 & 99500 & 73000 & 628500 \\
\hline 1984 & 678500 & 360500 & 107500 & 277000 & 494000 & 1917500 \\
\hline 1985 & 991000 & 94500 & 127500 & 54500 & 131000 & 1398500 \\
\hline 1986 & 1495500 & 613000 & 162000 & 303500 & 198000 & 2772500 \\
\hline 1987 & 1021000 & 875500 & 131500 & 761500 & 673000 & 3462500 \\
\hline 1988 & 884000 & 357500 & 130000 & 241000 & 383000 & 1995500 \\
\hline 1989 & 73500 & 121000 & $\times x$ & 192500 & 207000 & 594000 \\
\hline 1990 & 545500 & 552500 & 46500 & 289500 & 64000 & 1498000 \\
\hline \hline Mean & 809000 & 337500 & 113000 & 314500 & 331000 & 1873000 \\
value & & & & & & \\
\hline
\end{tabular}

xx: no results due to very low values 
Table 3.

\begin{tabular}{|c|c|c|}
\hline \multicolumn{3}{|c|}{ AKRONERI CAPE } \\
\hline \multicolumn{3}{|c|}{ Shoreline evolution (erosion) 1945-2002 } \\
\hline Number of years & Max. erosion (m) & Max. erosion rate (m/year) \\
\hline 58 & 780 & 12.6 \\
\hline \multicolumn{3}{|c|}{ Shoreline evolution (erosion) 2002-2007 } \\
\hline Number of years & Max. erosion (m) & Max. erosion rate (m/year) \\
\hline 6 & 27 & 4.5 \\
\hline \multicolumn{3}{|c|}{ KERAMOTI BAY } \\
\hline \multicolumn{3}{|c|}{ Shoreline evolution (accretion) 1945-2002 } \\
\hline Number of years & Max. accretion (m) & Max. accretion rate (m/year) \\
\hline 58 & 250 & 4.0 \\
\hline \multicolumn{3}{|c|}{ Shoreline evolution (accretion) 2002-2007 } \\
\hline Number of years & Max. accretion (m) & Max. accretion rate (m/year) \\
\hline 6 & 45 & 7.5 \\
\hline \multicolumn{3}{|c|}{ NESTOS RIVER DELTA } \\
\hline \multicolumn{3}{|c|}{ Shoreline evolution (accretion) 1945-2002 } \\
\hline Number of years & Max. accretion (m) & Max. accretion rate (m/year) \\
\hline 58 & 1100 & 17.7 \\
\hline \multicolumn{3}{|c|}{ Shoreline evolution (accretion) 2002-2007 } \\
\hline Number of years & Max. accretion (m) & Max. accretion rate (m/year) \\
\hline 6 & 180 & 30 \\
\hline \multicolumn{3}{|c|}{ Shoreline evolution (erosion) 2002-2007 } \\
\hline Number of years & Max. erosion (m) & Max. erosion rate (m/year) \\
\hline 6 & 160 & 26.7 \\
\hline
\end{tabular}


Table 4.

\begin{tabular}{|c|c|c|c|c|c|c|c|}
\hline \multicolumn{8}{|c|}{ 1945-2002 } \\
\hline No. & $\begin{array}{c}\text { Erosion } \\
\text { area }\left(\mathrm{m}^{2}\right)\end{array}$ & No. & $\begin{array}{l}\text { Accretion } \\
\text { area }\left(\mathrm{m}^{2}\right)\end{array}$ & No. & $\begin{array}{c}\text { Erosion } \\
\operatorname{area}\left(\mathrm{m}^{2}\right)\end{array}$ & No. & $\begin{array}{l}\text { Accretion } \\
\text { area }\left(\mathbf{m}^{2}\right)\end{array}$ \\
\hline E1 & 94.84 & A1 & 296.83 & E21 & 4397.39 & A21 & 0.05 \\
\hline E2 & 6.54 & A2 & 42.78 & E22 & 45.12 & A22 & 18074.80 \\
\hline E3 & 692723.77 & A3 & 56399.30 & E23 & 38.46 & A23 & 1321.38 \\
\hline E4 & 316.90 & A4 & 26084.96 & E24 & 49.54 & A24 & 82.07 \\
\hline E5 & 1.85 & A5 & 0.12 & E25 & 2215.91 & A25 & 7.27 \\
\hline E6 & 1.83 & A6 & 0.03 & E26 & 7294.45 & A26 & 0.13 \\
\hline E7 & 5.89 & A7 & 0.11 & E27 & 144.41 & A27 & 141.07 \\
\hline E8 & 0.71 & A8 & 0.16 & E28 & 13385.88 & A28 & 144.65 \\
\hline E9 & 17.11 & A9 & 0.24 & E29 & 206435.09 & A29 & 422317.52 \\
\hline E10 & 0.05 & A10 & 5.44 & E30 & 89337.50 & A30 & 949.18 \\
\hline E11 & 0.46 & A11 & 2.64 & E31 & 111.17 & A31 & 171134.08 \\
\hline E12 & 0.24 & A12 & 0.54 & E32 & 1279.47 & A32 & 2.55 \\
\hline E13 & 31.71 & A13 & 30.50 & E33 & 25.48 & A33 & 1.31 \\
\hline E14 & 2920.84 & A14 & 196.16 & E34 & 308391.43 & A34 & 1539166.33 \\
\hline E15 & 1081.74 & A15 & 0.74 & & & A35 & 0.01 \\
\hline E16 & 89.06 & A16 & 103.14 & & & A36 & 94.65 \\
\hline E17 & 4582.99 & A17 & 5425.24 & & & A37 & 47.64 \\
\hline E18 & 0.02 & A18 & 14.80 & & & A38 & 0.14 \\
\hline E19 & 0.01 & A19 & 0.27 & & & A39 & 11.26 \\
\hline E20 & 0.02 & A20 & 0.02 & & & A40 & 107.70 \\
\hline & & & & Total area & 1335027.90 & & 2242207.82 \\
\hline & & & & (\%) change & 37.32 & & 62.68 \\
\hline
\end{tabular}


Table 5.

\begin{tabular}{|c|c|c|c|c|c|c|c|}
\hline \multicolumn{8}{|c|}{ 2002-2007 } \\
\hline No. & $\begin{array}{l}\text { Erosion } \\
\operatorname{area}\left(\mathbf{m}^{2}\right)\end{array}$ & No. & $\begin{array}{l}\text { Accretion } \\
\operatorname{area}\left(\mathbf{m}^{2}\right)\end{array}$ & No. & $\begin{array}{c}\text { Erosion } \\
\operatorname{area}\left(\mathbf{m}^{2}\right)\end{array}$ & No. & $\begin{array}{l}\text { Accretion } \\
\operatorname{area}\left(\mathbf{m}^{2}\right)\end{array}$ \\
\hline E1 & 1547.98 & A1 & 204.25 & E31 & 330.93 & A31 & 0.82 \\
\hline E2 & 56.55 & A2 & 125.09 & E32 & 63.78 & A32 & 1.59 \\
\hline E3 & 2422.28 & A3 & 166.29 & E33 & 13.49 & A33 & 0.44 \\
\hline E4 & 0.15 & A4 & 14.38 & E34 & 0.03 & A34 & 11.52 \\
\hline E5 & 0.05 & A5 & 2.56 & E35 & 0.10 & A35 & 1.32 \\
\hline E6 & 0.02 & A6 & 0.23 & E36 & 7.76 & A36 & 0.07 \\
\hline E7 & 0.73 & A7 & 0.06 & E37 & 1433.04 & A37 & 0.00 \\
\hline E8 & 0.20 & A8 & 0.11 & E38 & 0.02 & A38 & 0.27 \\
\hline E9 & 0.88 & A9 & 0.01 & E39 & 0.10 & A39 & 7.75 \\
\hline E10 & 13.42 & A10 & 0.02 & E40 & 2.39 & A40 & 0.07 \\
\hline E11 & 3737.00 & A11 & 172.55 & E41 & 43.95 & A41 & 17.92 \\
\hline E12 & 301.40 & A12 & 0.00 & E42 & 0.06 & A42 & 31.18 \\
\hline E13 & 0.24 & A13 & 0.13 & E43 & 4.86 & A43 & 0.06 \\
\hline E14 & 0.00 & A14 & 0.38 & E44 & 0.06 & A44 & 370.15 \\
\hline E15 & 1.76 & A15 & 966.25 & E45 & 53.68 & A45 & 176.25 \\
\hline E16 & 2.56 & A16 & 3.37 & E46 & 0.00 & A46 & 0.08 \\
\hline E17 & 15.02 & A17 & 2.89 & E47 & 6.48 & A47 & 0.09 \\
\hline E18 & 939.61 & A18 & 0.29 & E48 & 362.44 & A48 & 103.96 \\
\hline E19 & 0.01 & A19 & 4.94 & E49 & 224.15 & A49 & 822.63 \\
\hline E20 & 0.10 & A20 & 0.08 & E50 & 11420.79 & A50 & 20538.29 \\
\hline E21 & 2675.72 & A21 & 121.85 & E51 & 4.34 & A51 & 509.81 \\
\hline E22 & 1.40 & A22 & 237.37 & E52 & 226.30 & A52 & 8507.23 \\
\hline E23 & 1130.85 & A23 & 1.46 & E53 & 3609.50 & A53 & 199.60 \\
\hline E24 & 0.08 & A24 & 0.02 & E54 & 1875.98 & A54 & 8237.88 \\
\hline E25 & 0.29 & A25 & 3.81 & E55 & 0.03 & A55 & 896.25 \\
\hline E26 & 0.62 & A26 & 1.23 & E56 & 0.13 & A56 & 124.15 \\
\hline E27 & 5.37 & A27 & 688.33 & E57 & 0.00 & A57 & 0.00 \\
\hline E28 & 0.01 & A28 & 0.01 & E58 & 6275.97 & A58 & 0.18 \\
\hline E29 & 16790.66 & A29 & 21.85 & E59 & 0.03 & A59 & 0.05 \\
\hline E30 & 160.73 & A30 & 0.00 & E60 & 112.74 & A60 & 920.13 \\
\hline
\end{tabular}


Table 5. (Continued)

\begin{tabular}{|c|c|c|c|c|c|c|c|}
\hline \multicolumn{8}{|c|}{ 2002-2007 } \\
\hline No. & $\begin{array}{c}\text { Erosion } \\
\operatorname{area}\left(\mathbf{m}^{2}\right)\end{array}$ & No. & $\begin{array}{l}\text { Accretion } \\
\text { area }\left(\mathbf{m}^{2}\right)\end{array}$ & No. & $\begin{array}{l}\text { Erosion } \\
\operatorname{area}\left(\mathbf{m}^{2}\right)\end{array}$ & No. & $\begin{array}{l}\text { Accretion } \\
\text { area }\left(\mathbf{m}^{2}\right)\end{array}$ \\
\hline E61 & 0.20 & A61 & 0.08 & E91 & 14.68 & A91 & 302.76 \\
\hline E62 & 7238.40 & A62 & 13.71 & E92 & 0.05 & A92 & 4.86 \\
\hline E63 & 0.23 & A63 & 0.01 & E93 & 0.01 & A93 & 0.13 \\
\hline E64 & 0.01 & A64 & 0.05 & E94 & 102.16 & A94 & 0.00 \\
\hline E65 & 4166.94 & A65 & 0.12 & E95 & 1.01 & A95 & 99.82 \\
\hline E66 & 0.05 & A66 & 0.02 & E96 & 172.50 & A96 & 0.15 \\
\hline E67 & 0.06 & A67 & 0.17 & E97 & 0.03 & A97 & 0.03 \\
\hline E68 & 42371.87 & A68 & 3563.91 & E98 & 0.05 & A98 & 0.01 \\
\hline E69 & 1168.22 & A69 & 241.08 & E99 & 0.11 & A99 & 0.26 \\
\hline E70 & 11245.39 & A70 & 5.21 & E100 & 0.04 & A100 & 3.08 \\
\hline E71 & 5765.18 & A71 & 51786.98 & E101 & 0.00 & A101 & 0.15 \\
\hline E72 & 119751.57 & A72 & 73497.93 & E102 & 1476.81 & A102 & 0.01 \\
\hline E73 & 41262.81 & A73 & 27448.07 & E103 & 0.00 & A103 & 443.46 \\
\hline E74 & 1290.60 & A74 & 1271.31 & E104 & 0.04 & A104 & 0.00 \\
\hline E75 & 11.24 & A75 & 9887.13 & E105 & 0.08 & A105 & 0.94 \\
\hline E76 & 14974.92 & A76 & 29723.13 & E106 & 28253.60 & A106 & 0.00 \\
\hline E77 & 12.76 & A77 & 59.32 & E107 & 0.22 & A107 & 0.01 \\
\hline E78 & 5.94 & A78 & 0.00 & E108 & 0.08 & A108 & 6.64 \\
\hline E79 & 0.04 & A79 & 0.02 & E109 & 0.08 & A109 & 0.00 \\
\hline E80 & 0.01 & A80 & 0.26 & E110 & 23975.00 & A110 & 0.00 \\
\hline E81 & 4015.37 & A81 & 160.85 & E111 & 0.43 & A111 & 0.82 \\
\hline E82 & 0.03 & A82 & 0.58 & E112 & 0.08 & A112 & 0.00 \\
\hline E83 & 0.02 & A83 & 0.01 & E113 & 11477.19 & A113 & 337.69 \\
\hline E84 & 0.08 & A84 & 245.62 & Total area & 374892.96 & & 243453.14 \\
\hline E85 & 234.98 & A85 & 0.05 & (\%) change & 60.63 & & 39.37 \\
\hline E86 & 0.33 & A86 & 0.01 & & & & \\
\hline E87 & 0.06 & A87 & 1.46 & & & & \\
\hline E88 & 0.06 & A88 & 125.67 & & & & \\
\hline E89 & 22.45 & A89 & 0.01 & & & & \\
\hline E90 & 0.04 & A90 & 0.00 & & & & \\
\hline
\end{tabular}



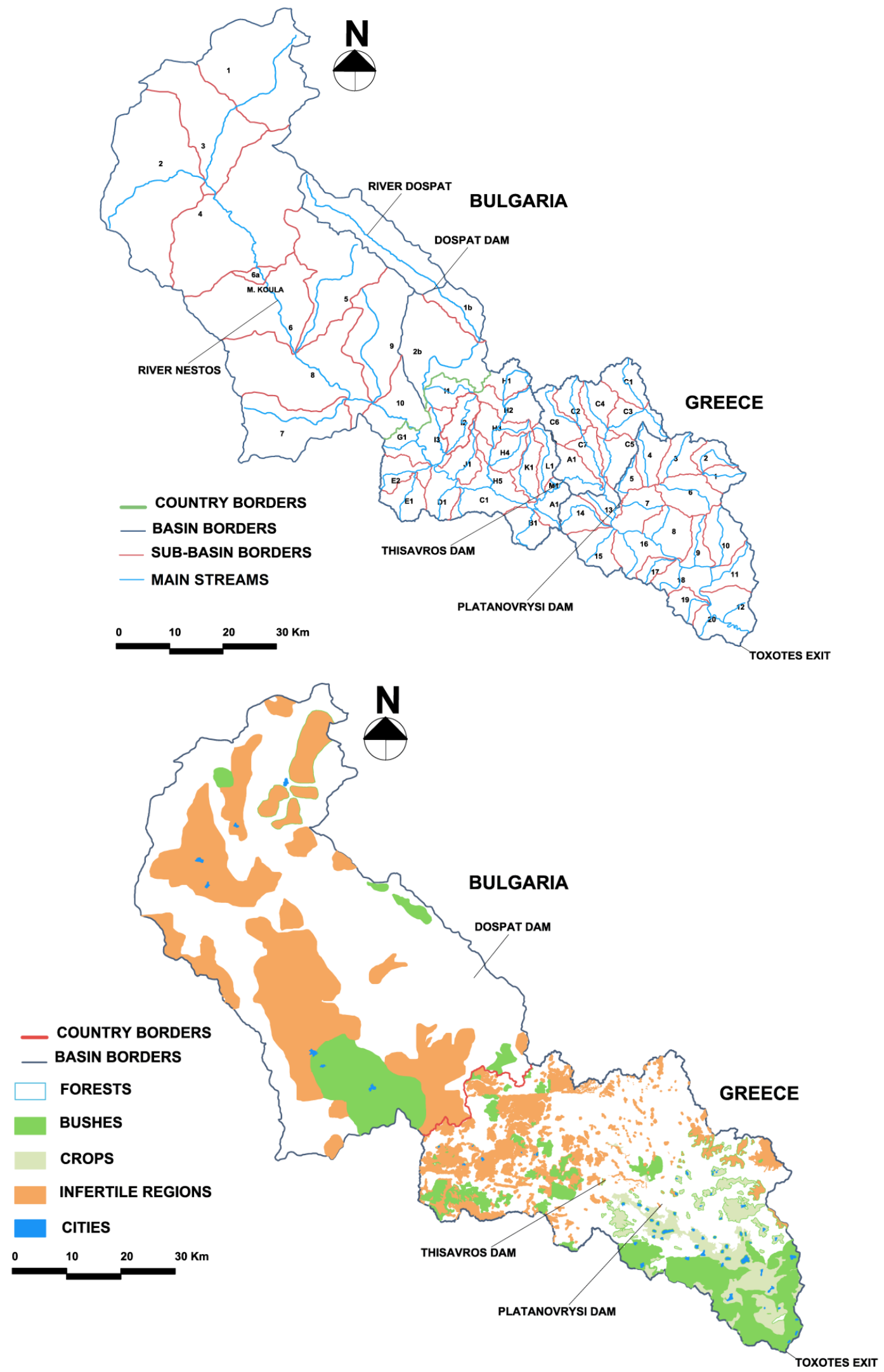

Fig. 1 

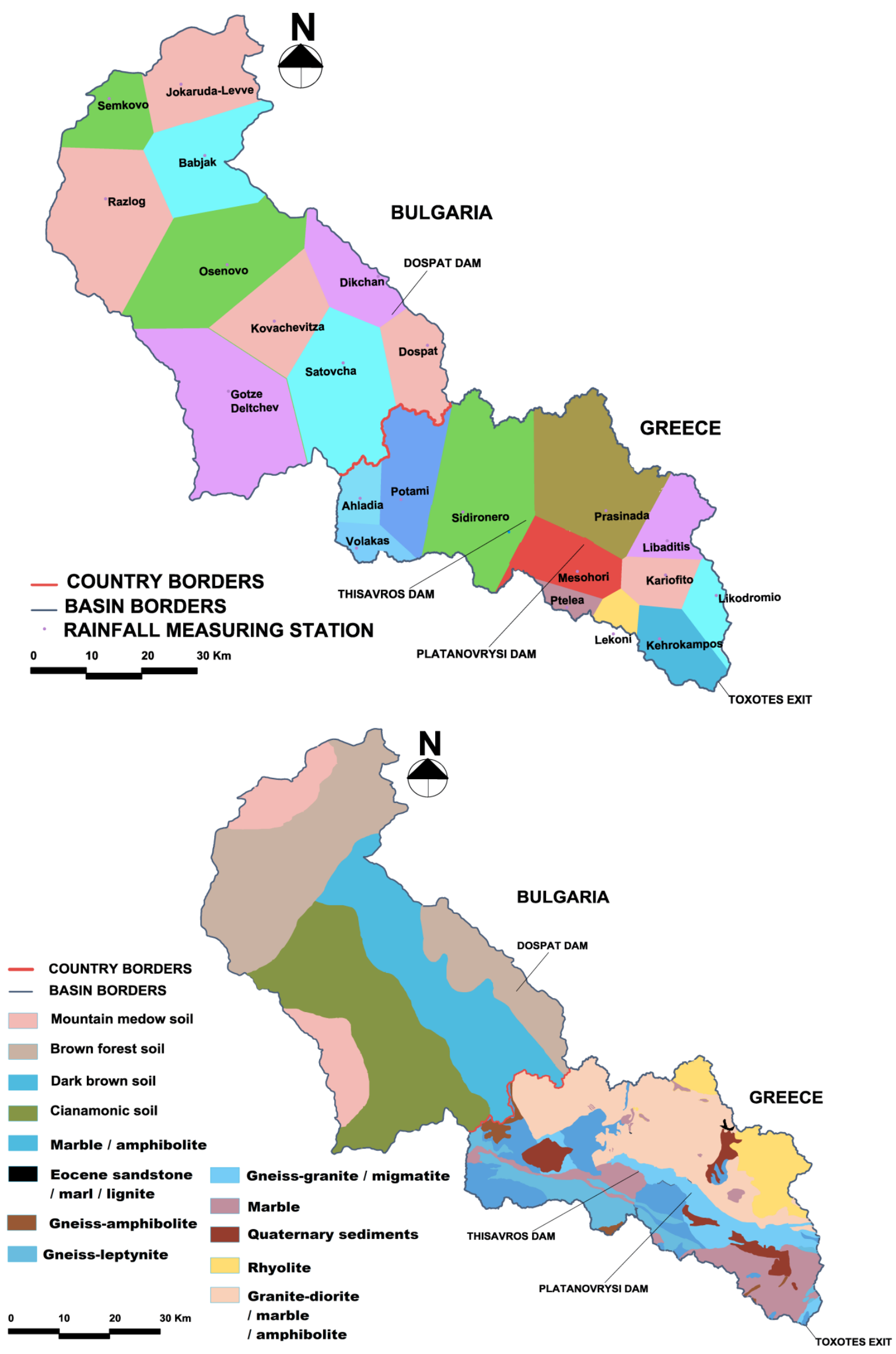

Fig. 2 


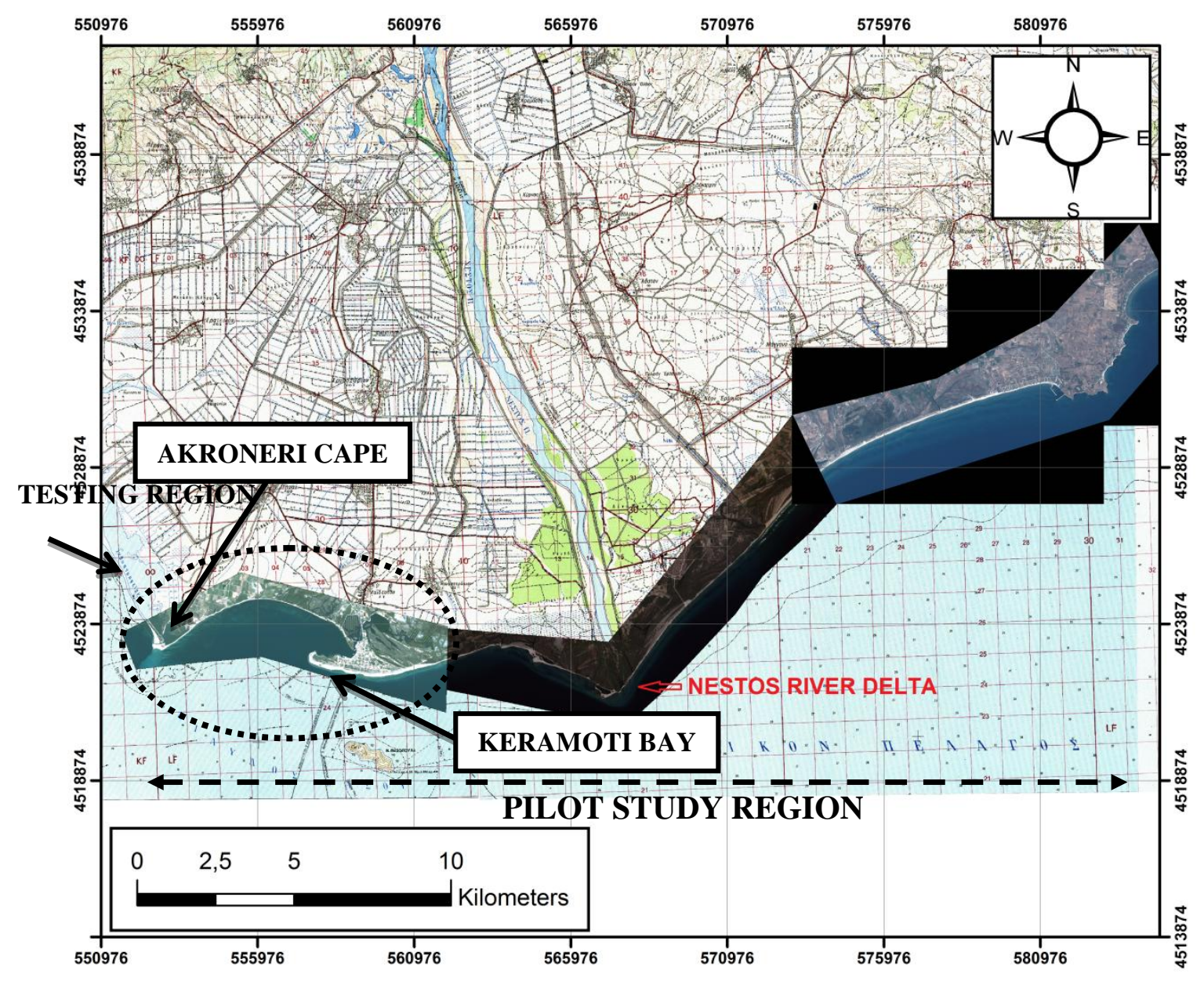

Fig. 3 


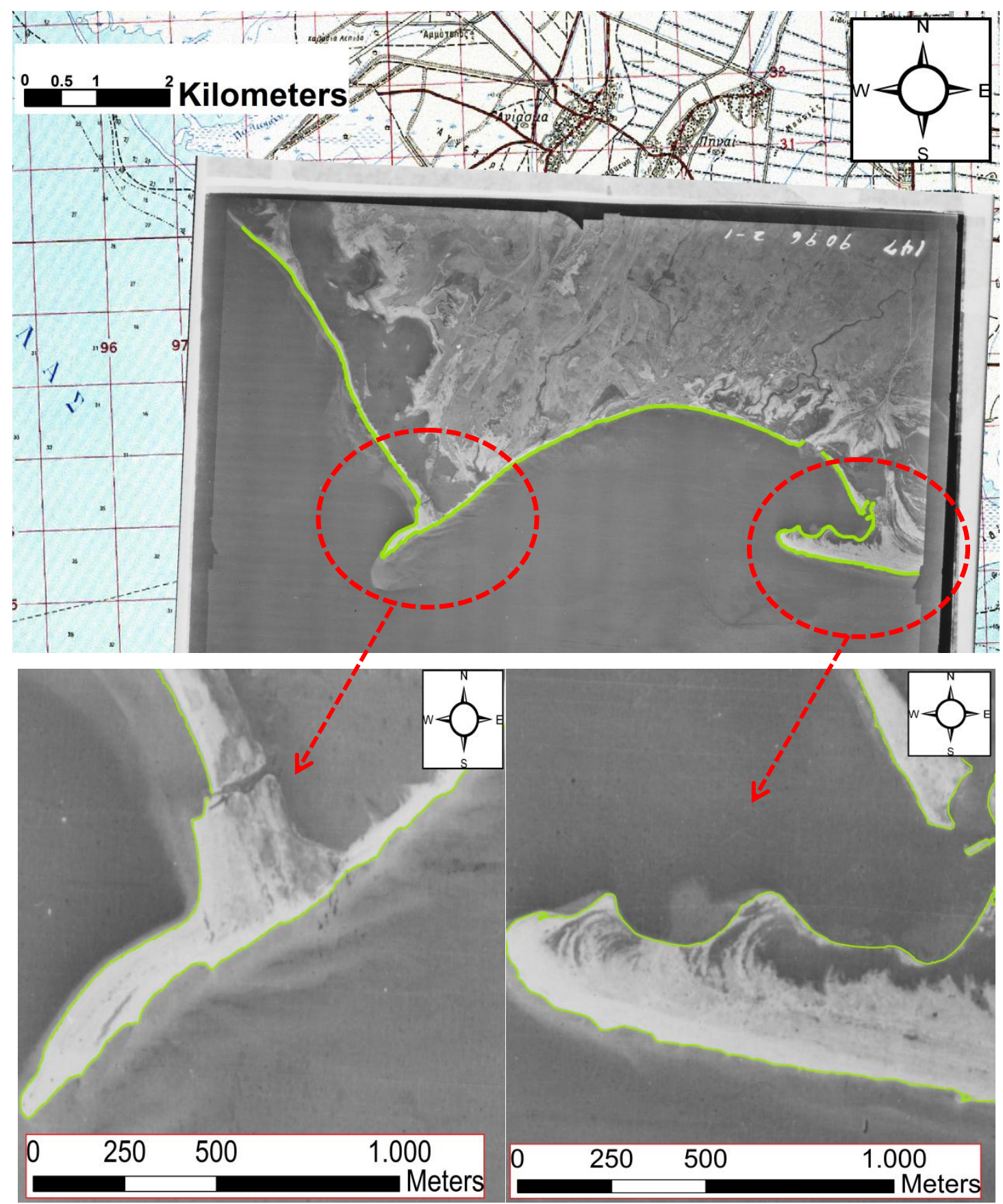

Fig. 4 


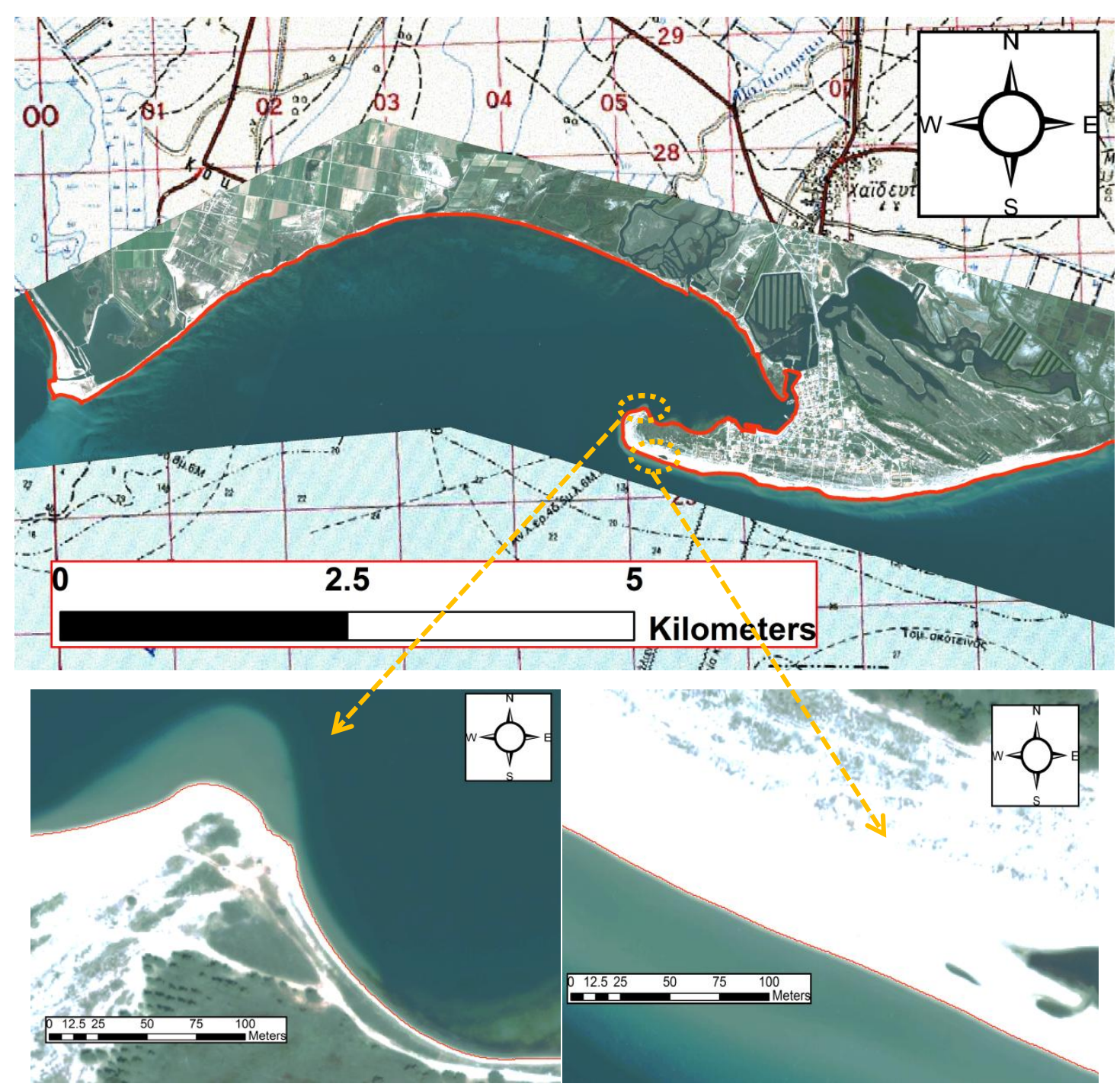

Fig. 5 


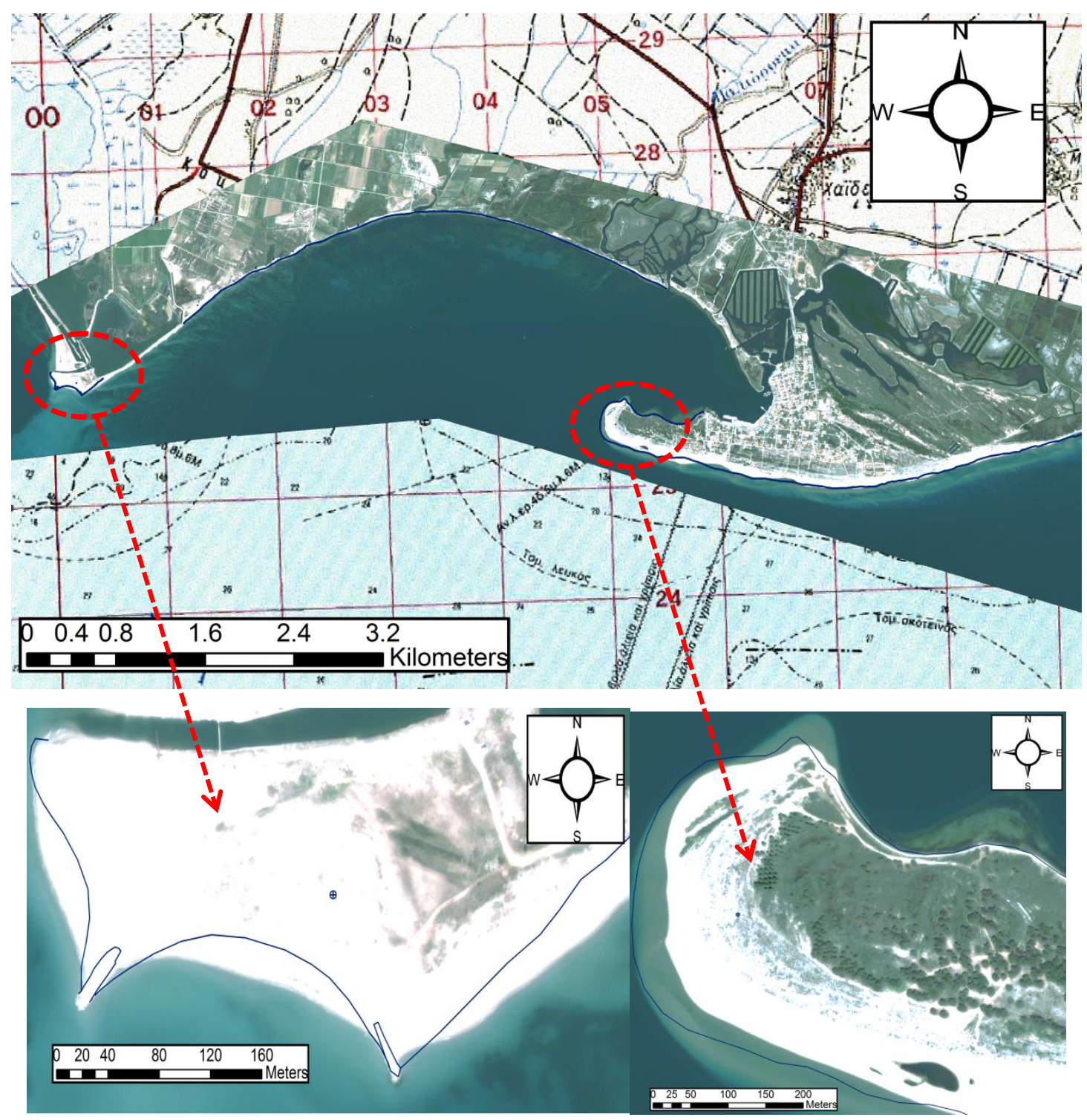

Fig. 6 


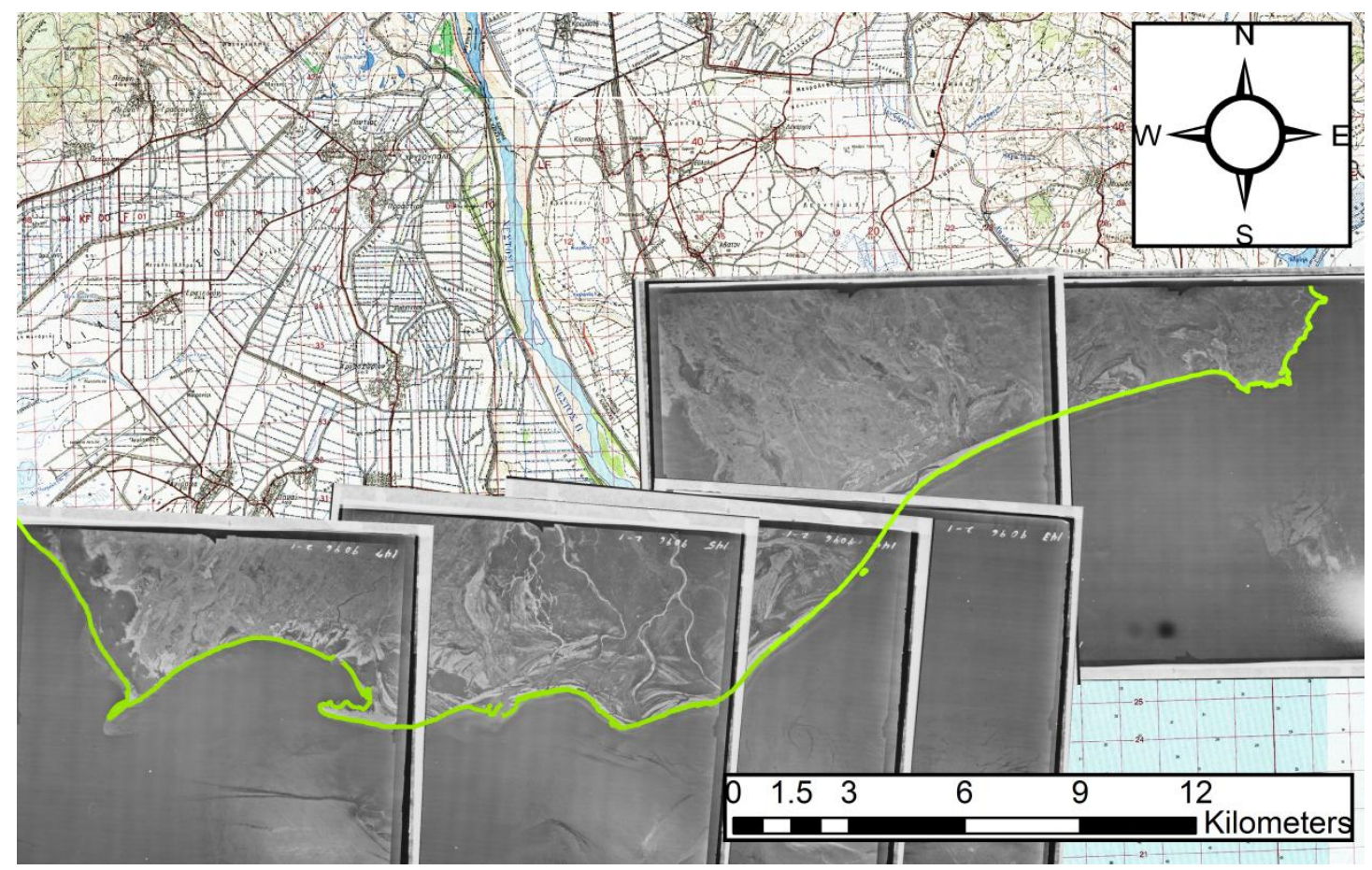

Fig. 7 


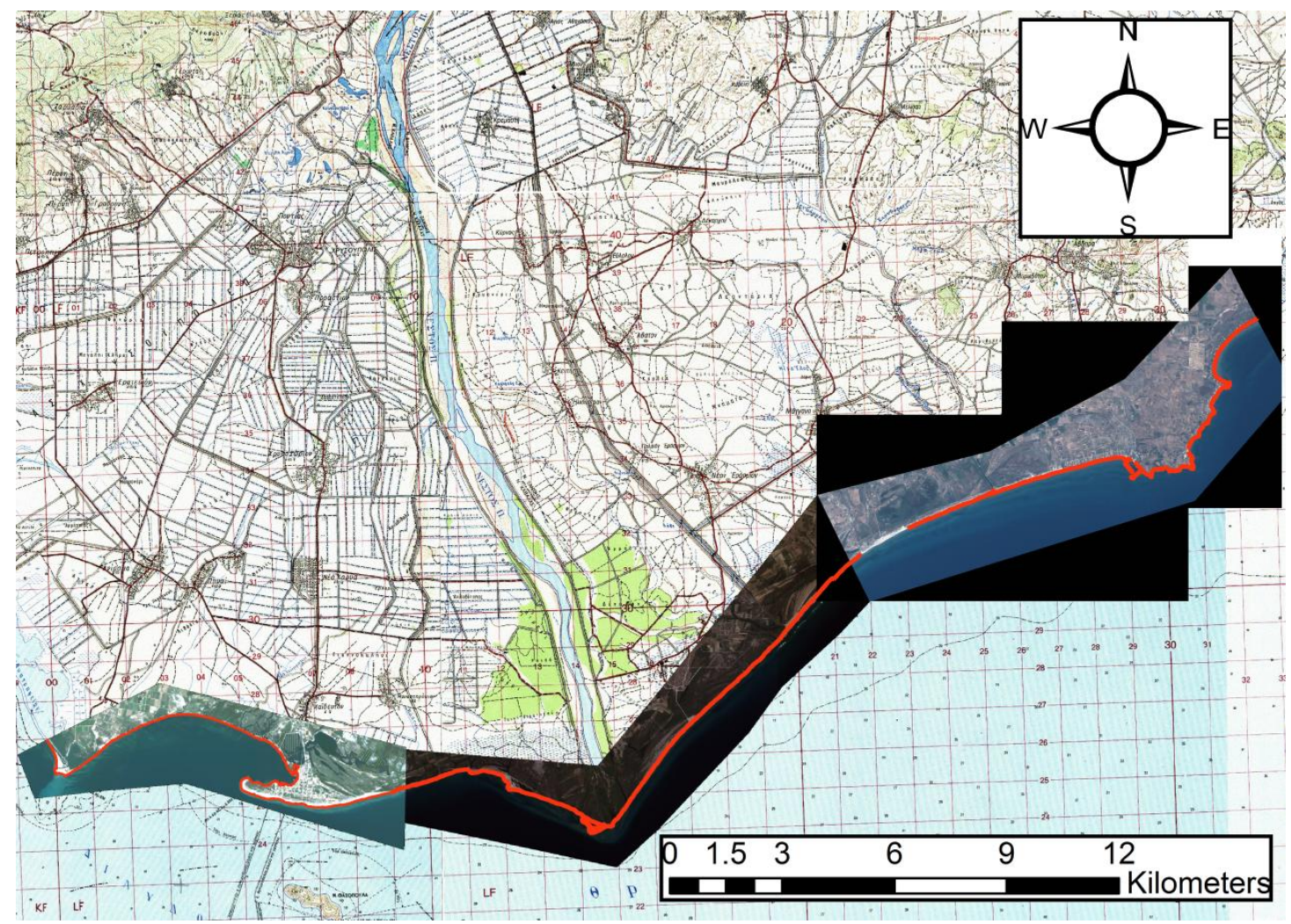

Fig. 8 


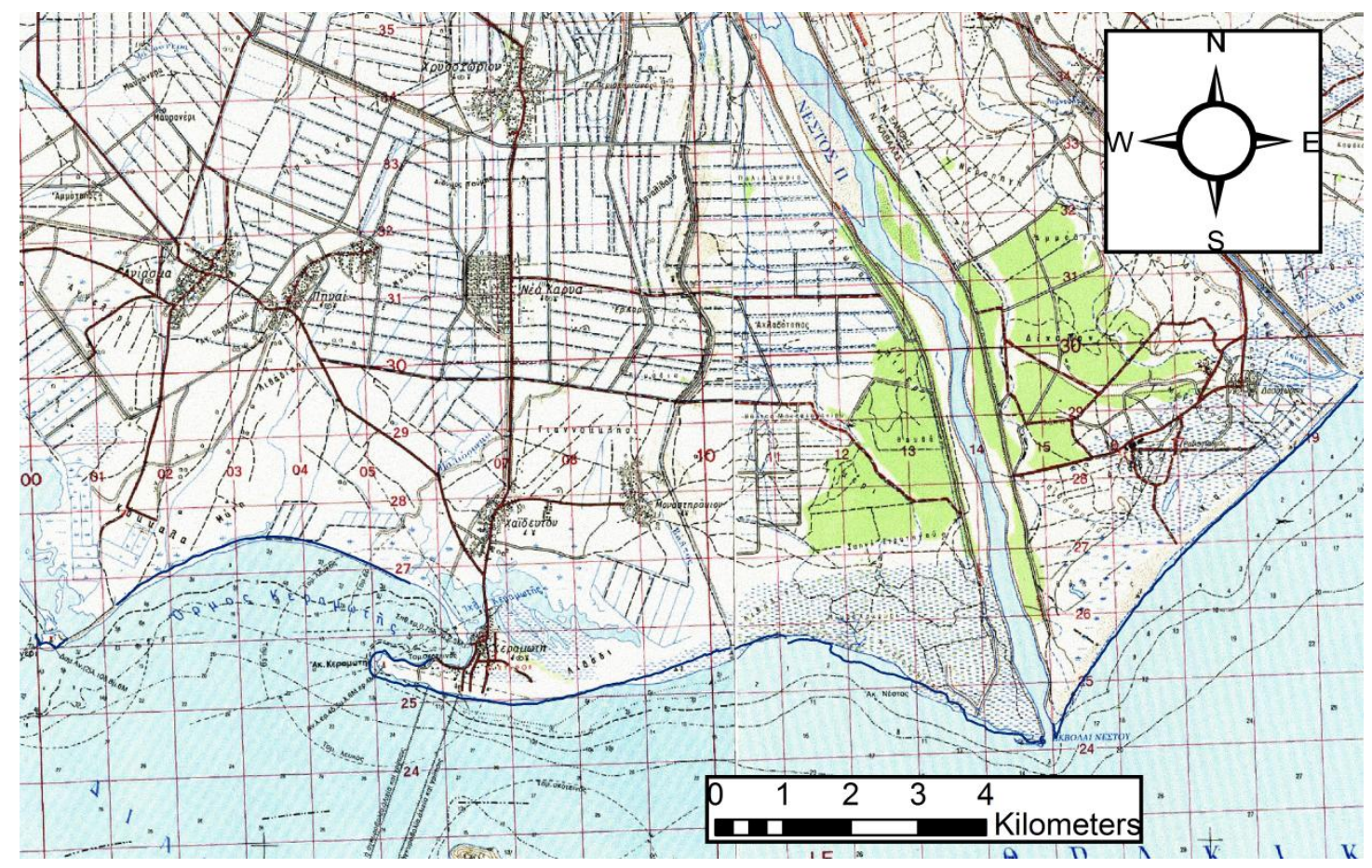

Fig. 9 


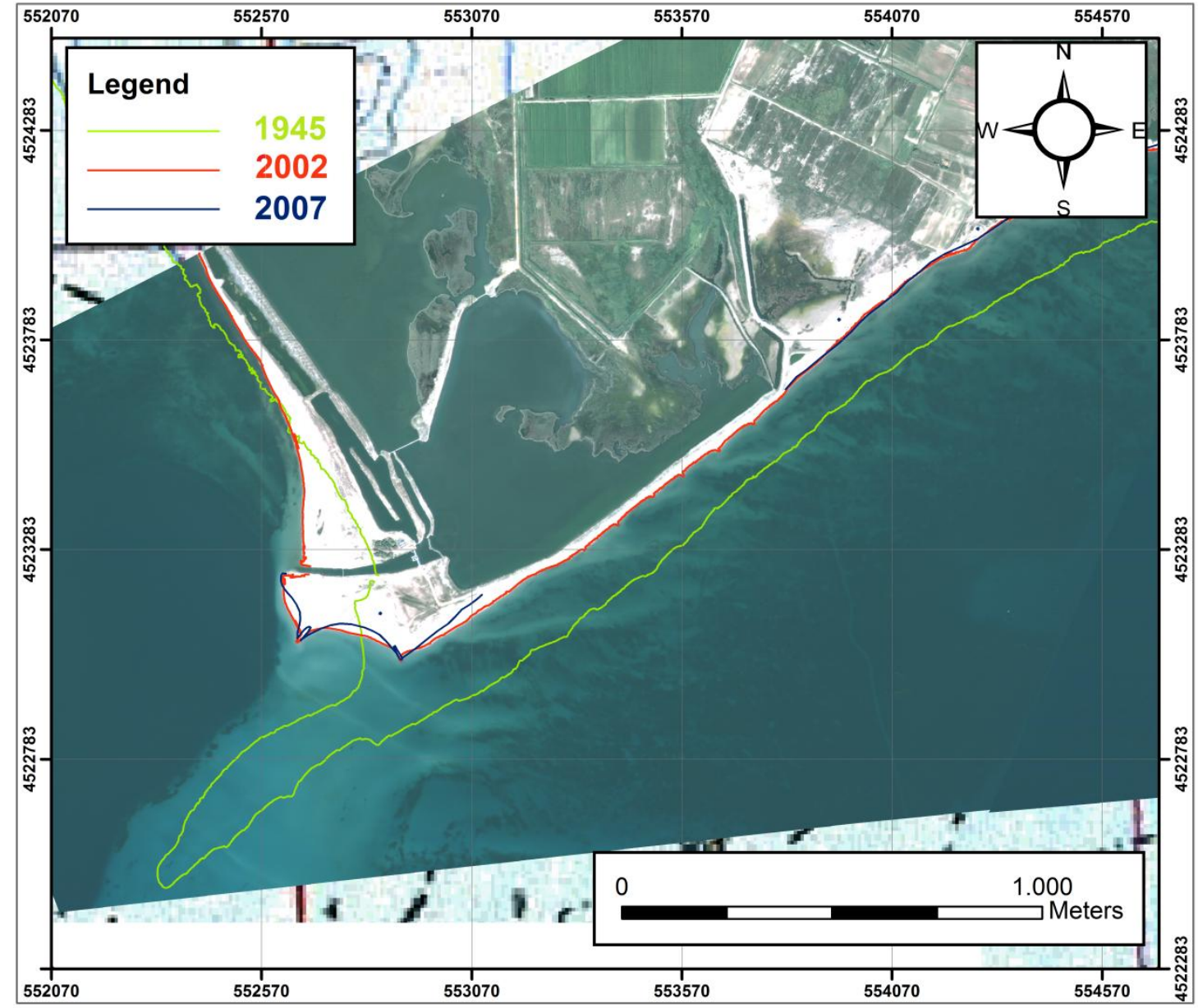

Fig. 10 


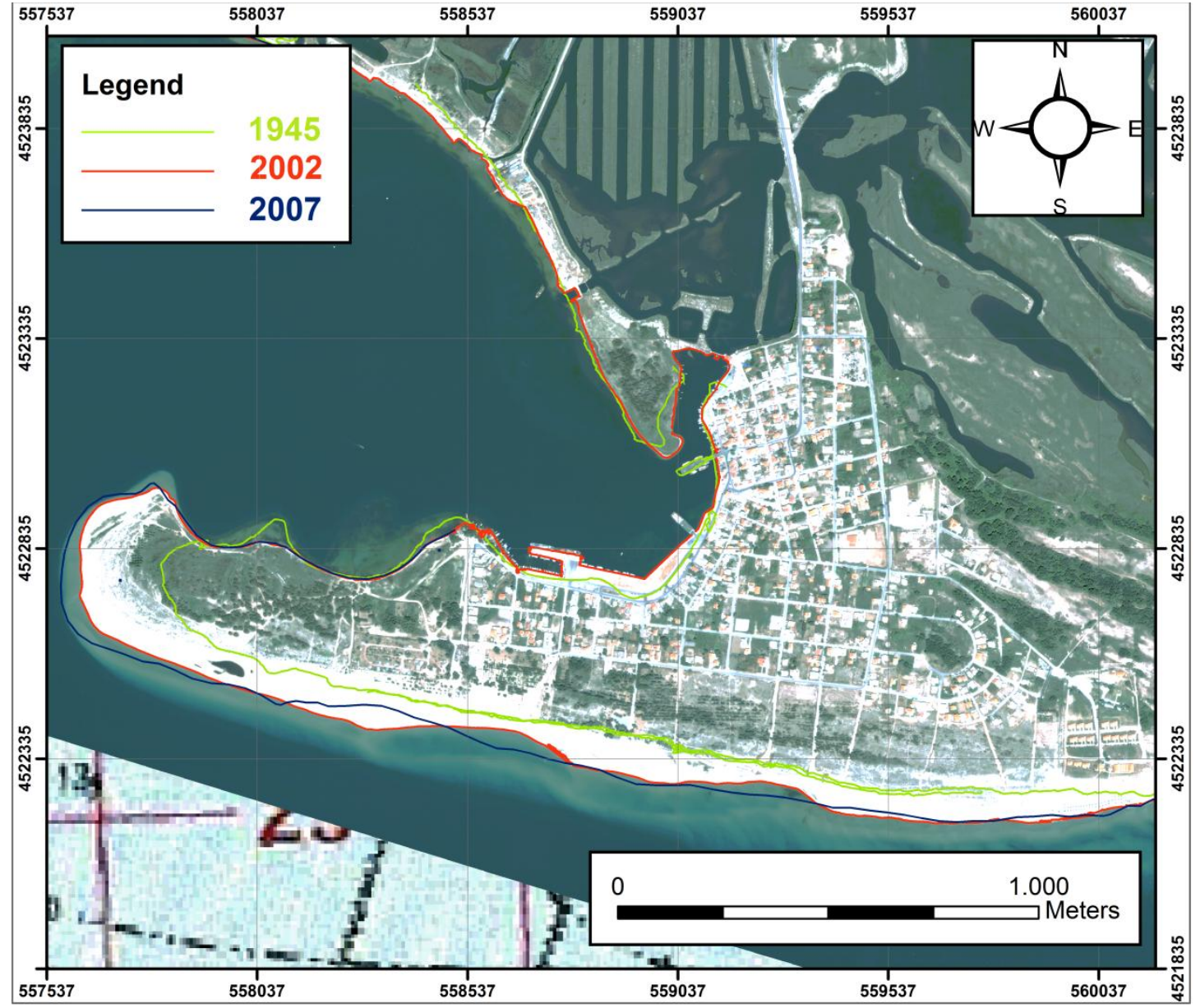

Fig. 11 


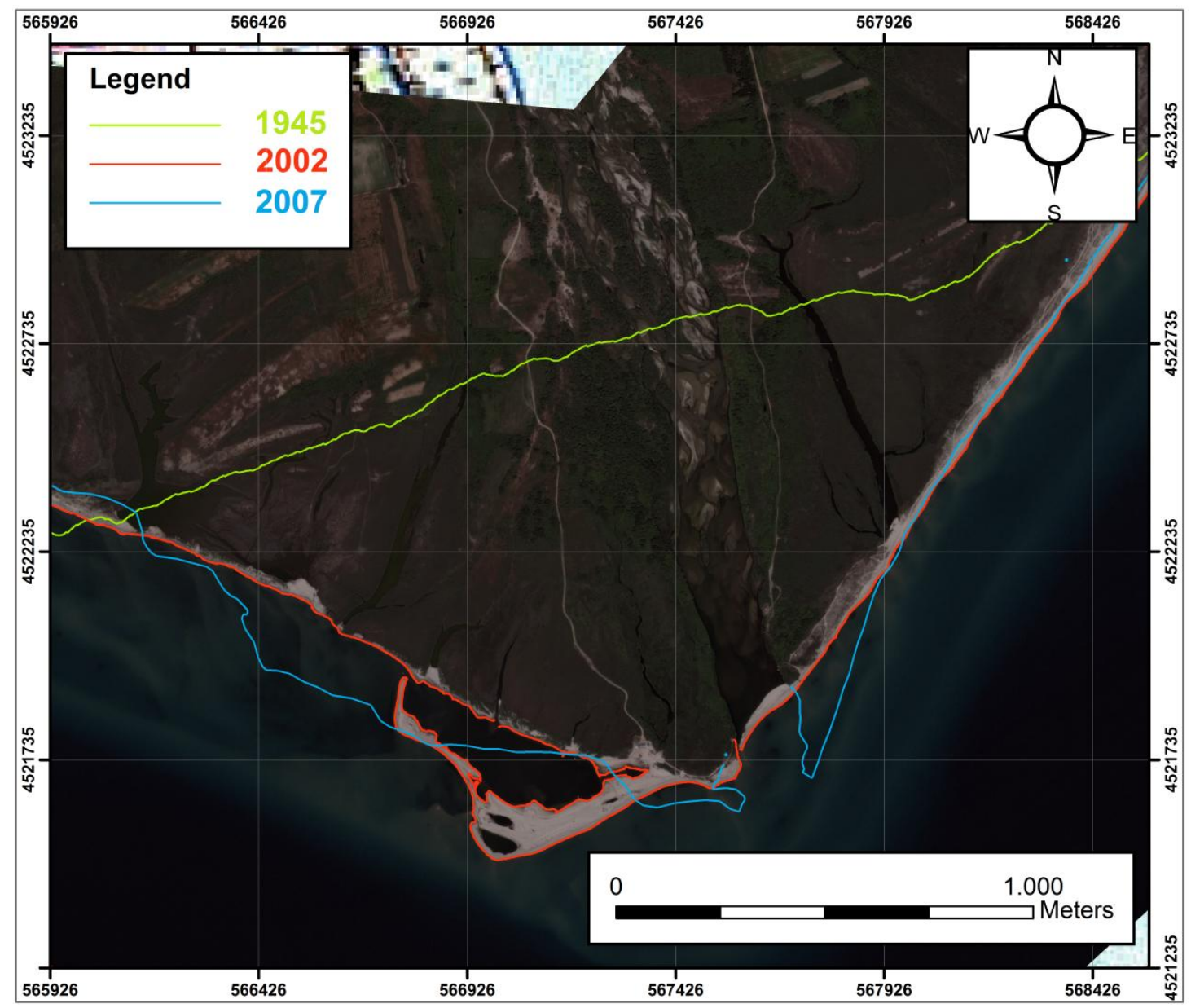

Fig. 12 


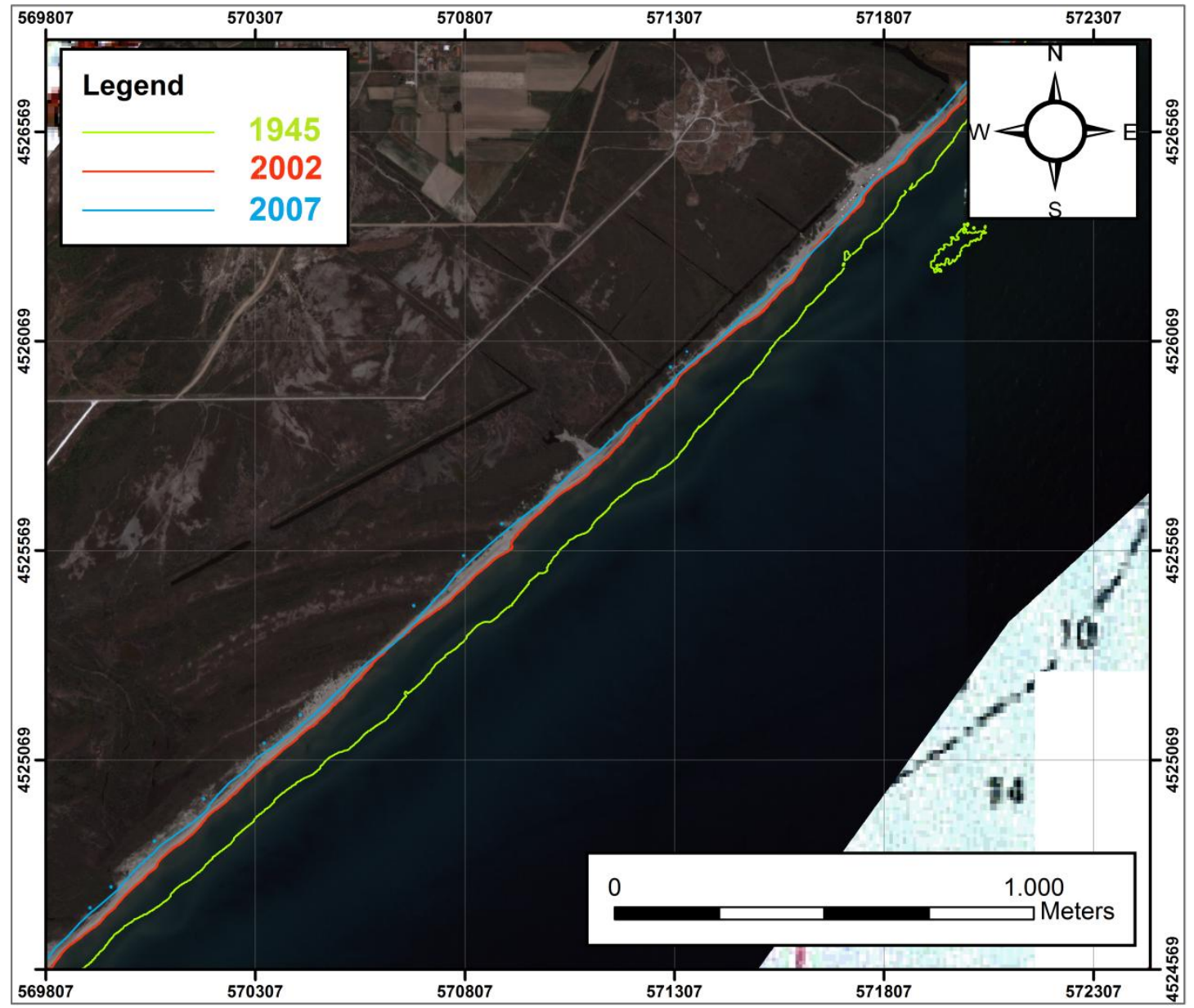

Fig. 13 

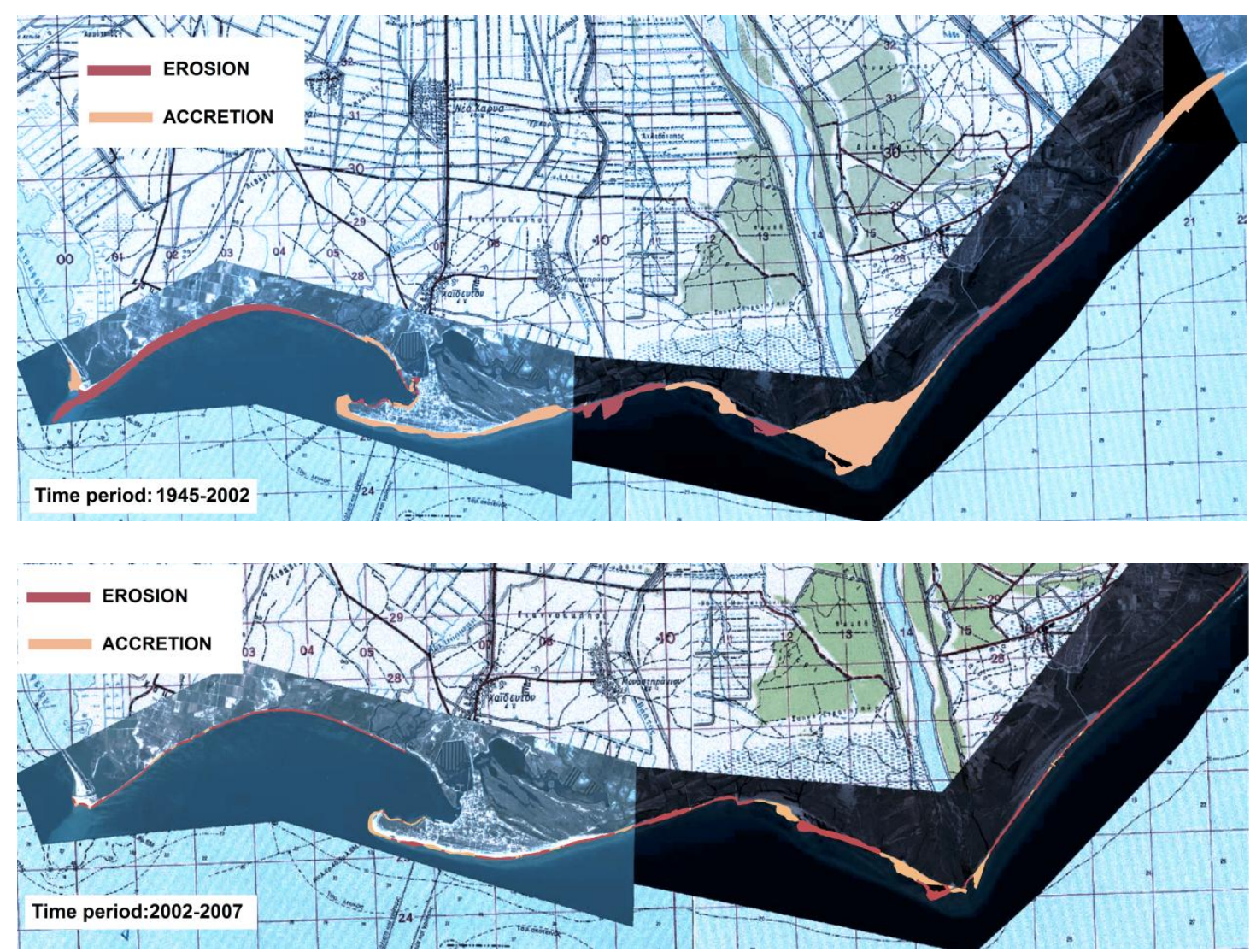

Fig. 14 